\title{
Long-distance Spore Transport: Methods of Measurement, Vertical Spore Profiles and the Detection of Immigrant Spores
}

\author{
By J. M. HIRST AND O. J. STEDMAN \\ Rothamsted Experimental Station, Harpenden, Hertfordshire
}

AND W. H. HOGG
Meteorological Office, Bristol

(Accepted for publication I3 March I967)

\begin{abstract}
SUMMARY
Airborne spores can be carried long distances, but little is known about the atmospheric transport processes involved or the rates at which spore clouds are depleted. Aircraft sampling is expensive and inevitably intermittent, and surface traps reveal only some of the processes involved. The best compromise is to combine surface and aircraft observations and to support both with detailed meteorological interpretation. Gravity slide traps exposed for I day indicate the arrival of spores less precisely than moving-slide impactors, which therefore provide a more accurate starting time for estimating the past track of spores from air trajectories. Catches of Puccinia graminis uredospores from continental European sources illustrated how immigration depends on the movement of atmospheric pressure systems and the gradients within them and suggested that in addition to surface air movement winds at the 700 and $500 \mathrm{mb}$. levels were important.

Aircraft of the Meteorological Research Flight, using suction impactors which operated approximately isokinetically, sampled air in the lower troposphere, both to ascertain vertical spore profiles over land and to intercept immigrant Puccinia graminis uredospores over the English Channel. The vertical distribution of spores seemed to be determined in the same way as that of other aerosol particles; atmospheric turbulence was a major factor and there were indications that wind shear, precipitation and surface deposition might be important. However, most spores are liberated periodically and so encounter different degrees of atmospheric turbulence depending on the diurnal periodicity of their concentration near the ground. Concentrations of $10^{4}$ spores $/ \mathrm{m}^{3}{ }^{3}$ occurred at heights up to $1000 \mathrm{~m}$. and hundreds $/ \mathrm{m}$. ${ }^{3}$ at $3000 \mathrm{~m}$. In unstable air spore concentrations often declined roughly logarithmically with height, but layers of stable air were often associated with abrupt changes of concentration. Details of vertical spore profiles also depended on the history of both the temperature profile and the spore cloud. Such factors tended to affect all spore types similarly: but occasionally some components, e.g. $P$. graminis uredospores, showed unique vertical profiles. One such profile, characterized by preferential 'erosion' of the spore cloud from air near the surface, may indicate travel remote from sources. Spores of plant pathogenic fungi were frequent in samples of air moving northward over the English Channel but their viability was not tested.
\end{abstract}

\section{INTRODUCTION}

Biological pollution of the atmosphere is chiefly by small organisms or propagules which can remain suspended in air, so most reports concern bacteria, insects or the spores of plants. This paper describes work done to study movements of plant pathogenic fungi, but pollen grains and the spores of saprophytic fungi are also mentioned. 
The establishment of plant pathogens in areas previously free from them usually provokes discussion about their transport. There is often good reason to attribute introduction to increased travel or trade in plants, but there is also evidence that fungus spores can travel long distances in air, although the frequency, extent, range or direction of such transport cannot yet be predicted. Many factors, both physical and biological, influence the sequence of processes which biologists often include in the term 'dispersal', from the release of spores at one site to their establishment elsewhere. Our observations concern only atmospheric transport, and do not deal with measurements of source strength, spore viability, deposition or establishment. However, because knowledge of these processes is necessary to understand the mechanism of transport, some relevant literature must be mentioned.

Pollen from tall plants can fall directly into turbulent air, but prostrate plants and microfungi often require vectors or special discharge mechanisms to carry their pollen or spores across the thin 'boundary-layers' close to surfaces, where airflow is laminar (Ingold, 1953, 1965; Gregory, 1961; Meredith, I963; Hirst \& Stedman, 1963). Near the ground the concentration of airborne spores fluctuates greatly and rapidly because of changes in weather and in the rate of spore liberation (Hirst, 1953; Gregory \& Hirst, 1957; Hamilton, 1959; Sreeramulu, I959; Kramer, Pady \& Wiley, 1963).

Attempts to predict the distance spores travel simply from their settling velocity and wind speed ceased when the role of turbulence in diffusion was accepted. Nevertheless, most spores are deposited closely around their sources. Conservative estimates suggest that in daytime <I to $25 \%$, and at night Io-90\% of spores (about $12 \mu$ to $32 \mu$ diam.) may be deposited within $40 \mathrm{~m}$. of sources close to the ground (Chamberlain, 1956; Gregory, Longhurst \& Sreeramulu, 196I ; Sreeramulu \& Ramalingam, 196r). In contrast, there is no agreed choice of the best parameters by which to predict the range and depletion of spore clouds, and contrasting theories are claimed to explain observed gradients (Schrödter, 1960; Gregory, 196I).

The 'velocity of spore deposition' (Chamberlain, 1956) from near-ground sources certainly depends on turbulence but seems greatest within a few metres of the source and then becomes constant at rather less than the terminal velocity of the spore (Chamberlain, I956; Gregory, 196I). Beyond $100 \mathrm{~m}$. from point sources, measurement of airborne spore concentration and deposition becomes difficult unless the source is prolific or a few particles are easy to detect. Thus there are very few measurements of the proportion of spores that escape deposition within $100 \mathrm{~m}$. and so could travel far. However, Gregory (I962) calculated that this 'escape fraction' could commonly be as much as $10 \%$. Many kilometres distant from sources the importance of gravitational settling and eddy-diffusion may change relative to other variables such as precipitation (May, 1958; Hirst, 1959; Gregory, 1961), vertical profiles of wind speed or temperature, and atmospheric pressure systems. Such factors are seldom included in existing dispersal theories but might have important and complex effects during prolonged travel. Until such effects are better understood, measured and included in dispersal theories there is little hope of accurately predicting economically significant transport of plant pathogens over long distances.

To measure how spore concentration varied with height to the limit of detectability, perhaps hundreds or thousands of miles downwind of large sources, as well as across the cloud to measure lateral dispersion, would be a prodigious task. Ideally such measurements should be repeated to show how changes in source strength, wind 
direction and turbulence affect dispersal. To collect such complete information may never be feasible, so it is necessary to consider how to understand the principles from simpler measurements. Measurements of spore concentration on the ground and from aircraft can be made complementary, and the value of both is enhanced by detailed meteorological interpretation. Networks of spore traps operated continuously at ground level are not prohibitively expensive and show something of the extent and movement of spore clouds. In contrast, aircraft have a unique ability for sampling vertical or horizontal spore profiles quickly, but their short flight duration and cost prevent continuous sampling.

\section{METHODS}

Measurement of spore concentration near the earth's surface

Christensen (1942) and Gregory (I96I) reviewed long-distance spore transport. None of the examples quoted has been more valuable to plant pathology than the discovery that epidemics of wheat stem rust in central North America were initiated by Puccinia graminis tritici uredospores blown from winter-sown crops in southern states (Stakman \& Hamilton, I939; Stakman \& Harrar, 1957; Craigie, 1957). Recent pollen deposits have also yielded exotic grains presumed to have been deposited from the air (King \& Kapp, I963; Hafsten, I95I).

Spore concentrations have been measured on long surface transects by car (Craigie, 1945) or more often by ships (Sreeramulu, I958; Gregory, 196I ; Sack, 1949). Marine observations have the important advantage that it is not necessary to select identifiable, and usually rare, migrant spores from among the whole flora, because all terrestrial propagules must be of distant origin.

No existing spore trap allows the whole airborne flora to be identified, nor does any accurately assess spore deposition on host surfaces. Most of the catches we report came from traps used primarily to study spores as respiratory allergens and sited on buildings up to $30 \mathrm{~m}$. above ground. Horizontal slides were exposed at Cardiff (I947 to I956) and at the Bishop Rock Lighthouse (I953 to I96I). At Cardiff from April I954 onwards moving slide impactors (Hirst, 1952) were used and sampled air continuously at Io $1 . / \mathrm{min}$., but the slides concerned were not scanned completely for Puccinia graminis uredospores until I957. For the periods described in Figs. 7, 8 and 12 the entire catch was scanned for $P$. graminis uredospores, and this permitted a threshold concentration of 2 spores $/ \mathrm{m}^{3}$ air to be detected. For commoner spores only a fraction of the slide was examined, allowing $10-20$ spores $/ \mathrm{m}^{3}$. to be detected.

When all types of spores were counted they were assigned to one of 35 categories (Gregory \& Hirst, 1957), ranging from 'unclassified', through form groups or broad taxonomic divisions, to a few identified as species. In presenting catches, the total concentration of all spore types has sometimes been used, or smaller categories, such as 'Cladosporium' and 'pollens', selected to illustrate the behaviour of particles of different mass but similar average diurnal periodicity near the ground. Fungus spores are between 2 and $200 \mu$ long (mostly 5 to $30 \mu$ ), they have settling velocities between 0.05 and $3.0 \mathrm{~cm}$. $/ \mathrm{sec}$. with a mode considerably less than $1 \mathrm{~cm} . / \mathrm{sec}$., and different spores vary greatly in shape and ornamentation. Most pollen grains, like fungus spores, have a specific gravity close to I.O (Gregory, I96I) but are usually more nearly spherical, larger and, because of their greater mass, settle at 1 to $40 \mathrm{~cm}$. $/ \mathrm{sec}$., with a mode at about $3 \mathrm{~cm} . / \mathrm{sec}$. 


\section{Meteorological interpretation}

To explain variations in catches of spores from distant sources the past tracks of the air sampled had to be estimated. Movement of air within atmospheric pressure systems is governed by (I) the earth's rotation; (2) the gradients of atmospheric pressure; (3) the forces generated by flow within pressure systems; (4) the friction of air moving over the surface (Meteorological Office, 1960). The 'geostrophic trajectories' which we estimated from surface synoptic charts depended mainly on the first two, so strictly the 'surface' track applies to the movement of unretarded air, at 600-900 m., just above the friction layer over lowlands. Aerological charts, showing contours of the altitude of fixed pressure levels, were also used to estimate trajectories at the 700 and $500 \mathrm{mb}$. levels, roughly equivalent to heights of 3000 and $5600 \mathrm{~m}$. respectively.

Table I. Standard vector errors of position (in $\mathrm{km}$.) after stated periods (Hogg, I96I b)

$\begin{array}{lccccccc} & 6 \mathrm{hr} & \mathrm{I} 2 \mathrm{hr} & 24 \mathrm{hr} & 2 \text { days } & 3 \text { days } & 4 \text { days } & 5 \text { days } \\ \text { Surface } & 78 & \text { I09 } & 156 & 22 \mathrm{I} & 269 & 3 \mathrm{I2} & 348 \\ 700 \mathrm{mb} . & - & 222 & 315 & 445 & 545 & 628 & 684 \\ 500 \mathrm{mb} . & - & 31 \mathrm{I} & 439 & 623 & 762 & 880 & 984\end{array}$

The process of estimating trajectories incurs several cumulative errors (Murray, 1954; Durst \& Davies, 1957); Table I shows the radius of the circle around the true position of a parcel of air within which about two-thirds of the geostrophic trajectories would end. The same errors apply to trajectories drawn in the reverse direction, from source to trap, so they affect the time of arrival as well as the direction of travel and it is reasonable to accept that spores may be caught sooner or later than expected. Uncertain air movement in weak pressure gradients, for example in an anticyclone, a ridge or col, can introduce large errors, particularly in 'surface' trajectories. Sometimes the choice lies between paths that eventually result in entirely different gradients for the possible trajectories; see, for example, the trajectory relating 00.o I on Io July I959 in Fig. I2. Each surface trajectory was based on a series of synoptic charts, usually at $6 \mathrm{hr}$ intervals. The successive past positions of a parcel of air that had reached a specified target at a given time (e.g. a spore trap when spores were first caught) were estimated by working backwards. The resulting trajectory was the best estimate for the path of the air. Surface trajectories were followed up to 5 days. Upper air trajectories were drawn from I2-hourly aerological charts and, because of the greater wind speed at these levels, the tracking was not usually continued beyond 2 or 3 days.

The vertical distribution of spores is often much affected by atmospheric stability. When the air is unstable, any vertical displacement (upward or downward) is likely to continue. When it is stable, such vertical displacement will not continue and the air will return to its original position. In general terms, therefore, air mixes more when it is unstable, and so has more effect on the distribution of airborne spores.

The stability of the air can be determined from a knowledge of the temperature lapse rate, which is the rate at which the temperature decreases with height. When the lapse rate of the air exceeds the dry adiabatic lapse rate $\mathrm{I}^{\circ} \mathrm{C} / \mathrm{I} 00 \mathrm{~m} .\left(3^{\circ} / \mathrm{I} 000 \mathrm{ft}\right.$. $)$ it is said to be absolutely unstable; when it is less than the saturated adiabatic lapse rate (about 
$0.5 \% 100 \mathrm{~m}$. or $\mathrm{I} .5^{\circ} / 1000 \mathrm{ft}$. at low levels) it is absolutely stable. When it lies between these two it is said to be conditionally unstable, i.e. it is stable when unsaturated but becomes unstable when it is lifted enough to become saturated. On several diagrams, temperature-height diagrams indicate the stability of the air, in so far as it can be determined without a knowledge of its humidity, and the dry and saturated adiabatic lapse rates are given for reference.

\section{Measurement of spore concentrations with aircraft}

The first collections of fungus spores high above ground were made with the aid of kites and balloons (see Gregory, 196I); aeroplanes were first used in I92 I (Stakman, Henry, Curran \& Christopher, 1923). Most workers have used the air speed to impact spores on sticky obstacles such as microscope slides (Stakman et al. 1923), small cylinders (Rempe, I937), Petri dishes (Dillon Weston, I929; Polunin \& Kelly, 1952) or small square-section rods (Asai, I960). These, and suction traps (which probably sampled at velocities very different from the forward speed of the aircraft), showed that pollens and fungus spores could be abundant in the lower troposphere and that some of them were alive.

All the collections we report were made by aircraft and crews of the Meteorological Research Flight, Farnborough. The Hastings or Varsity aircraft used carried a modified impactor of the type described by Pasquill (I955; see also Hirst \& Hurst, I967, Pl. I). Samples were collected through a small circular sampling head, mounted horizontally and coaxial with the end of a long tube, which allowed the head to be projected $0.6 \mathrm{~m}$. clear of the fuselage. This tube was mounted on a transverse carriage so that it could be retracted into the fuselage. The inboard end had a suction outlet, a vacuum gauge and a knob for selecting $\mathrm{I} 20$ positions. Each position was separated by $3^{\circ}$, or $1.62 \mathrm{~mm}$., on the sampling drum, which was $6.15 \mathrm{~cm}$. in diam. and $2.4 \mathrm{~cm}$. wide and mounted centrally within the sampling head.

The sampling tube had a circular orifice $0.3 \mathrm{~cm}$. diam. converting to a $\mathrm{I} \mathrm{cm}$. long slit $0.33 \mathrm{~mm}$. wide, separated from the trapping surface by $0.5 \mathrm{~mm}$. Pressure drop across the orifice was calibrated to give theoretically isokinetic sampling at all heights up to $3000 \mathrm{~m}$. At $\mathrm{I} 60$ and 180 knots ( $\mathrm{I}$ knot $=\mathrm{I}$ nautical mile $/ \mathrm{hr}=\mathrm{r} \cdot 853 \mathrm{~km}$. $/ \mathrm{hr}$ ) these were $\mathrm{I} 52$ and $\mathrm{I} 78 \mathrm{~mm}$. Hg, giving airflow rates of 35 and $39 \mathrm{l} / \mathrm{min}$. Spores were impacted on an adhesive surface prepared and mounted as for ground-level traps (Hirst, 1953) except that a strip of transparent plastic film ('Melinex O', a clear polyethylene terephthalate film supplied by Imperial Chemical Industries Ltd., Plastics Division, Welwyn Garden City, Herfordshire., $0.127 \mathrm{~mm}$. thick) was used instead of a glass slide. This film was evenly coated with melted petroleum jelly, containing 10 \% of paraffin wax (m.p. 54 $4^{\circ}$. After gradual cooling the Melinex strip was wrapped tightly around the sampling drum to which the ends were fixed with double-sided adhesive plastic tape. The drum was then bolted into a tin and sealed to prevent contamination.

Close to the ground, in summer, there may often be several hundred thousand spores $/ \mathrm{m}^{3}$ air. Efficient spore traps then catch so many spores that occasional contaminants are seldom important, but at altitudes where spores are rare contaminants matter more. Although the Melinex strips were coated in a room with a filtered air supply, it would be naive to suppose that contamination was eliminated or did not occur when drums were fitted and removed in the aircraft. Contamination, estimated by 'background counts' on areas where no sample trace was deposited, was rare and 
restricted to occasional Cladosporium conidia, so little reliance should be placed in very small catches of these.

Because external air sampling was isokinetic with air speed, intake velocity was fast and even small particles were impacted efficiently by the orifice; traces contained much more fine dust than on the ground traps, which were designed to eliminate this. The dense deposits make the surface less adhesive and are difficult to count. Therefore, the duration of sampling was varied with height; usually I min. samples, which at I 80 knots represent a core of air $3 \mathrm{~mm}$. diameter and 3 nautical miles $(5.56 \mathrm{~km}$.) long, were taken below $1800 \mathrm{~m}$. and $2 \mathrm{~min}$. samples at greater heights. To decrease the detection threshold concentration and to allow sampling errors to be assessed, three consecutive samples were taken as replicates for each height when circling during ascents, or at each 'position' when making horizontal traverses. A single spore in a I min. sample represents approximately 30 spores $/ \mathrm{m} .{ }^{3}$ air, and scanning a triplet of traces provided approximately the same detection threshold as ground traps. Height and speed were usually constant during sampling, so a triplet of samples occupied at least 9 nautical miles of flight. The first sample of a triplet often contained more spores than the others; probably because some spores were impacted in the sampling orifice while flying between sampling positions with the impactor extruded but with suction off. From 196I this error was avoided by retracting the sampler whenever possible and taking a dummy sample immediately before each triplet to be counted. In presenting results from earlier flights we have omitted the first sample of a triplet wherever there was a long interval between groups of samples.

Special precautions were required to identify the precise areas on which samples of spore-free air were impacted. The Melinex strip was marked in the impactor, at least once every 20 sample-positions, with a trace of Lycopodium powder dispersed in front of the orifice while the pump was switched on momentarily. Exposed Melinex strips were removed from their sealed tins and drums in the laboratory, then laid on a transparent scale above the stage of a microscope. The scale was marked to correspond with the 120 sample-positions, so that with the Lycopodium marker traces at known positions the strip could be cut accurately into lengths and mounted as permanent microscopical preparations (Hirst, I953). The stage of the microscope used for counting was fitted with adjustable stops, set with the aid of the stage vernier and Lycopodium marker traces, to limit slide travel accurately to the areas where samples were deposited.

\section{The presentation of results}

Spore catches from aircraft have usually been expressed as the number deposited per unit area of the exposed sticky surface. Because so little is known of spore deposition and retention on sticky surfaces at aircraft speeds, the results are seldom comparable. Our sampling was volumetric and approximately isokinetic, so it was justifiable to convert the catches to concentrations in air.

Because vertical diffusion of spores depends much on thermal turbulence, easy comparison of the spore concentration and temperature profiles is desirable. Ideally, in the 'International Standard Atmosphere', temperature declines linearly at $6.5^{\circ} \mathrm{C} / \mathrm{kilo}-$ metre up to I I km., so it would be convenient if corresponding spore profiles could also be made linear. Johnson \& Penman (195I) found that vertical density profiles of aphids up to $600 \mathrm{~m}$. could often be straightened by plotting both height and concentration on log. scales. In Fig. I $b$ this method is compared with the linear scales of 
Fig. I $a$, using pollen catches by Rempe (1937). In Fig. I $b$ the bend in the curves above about $900 \mathrm{~m}$. makes them insensitive to changes of concentration at greater heights. We adopted a linear height scale and a log. scale for spore concentration (Fig. I $c$ ), because this provides the best means of showing small changes in concentration and of comparing spore and temperature profiles.
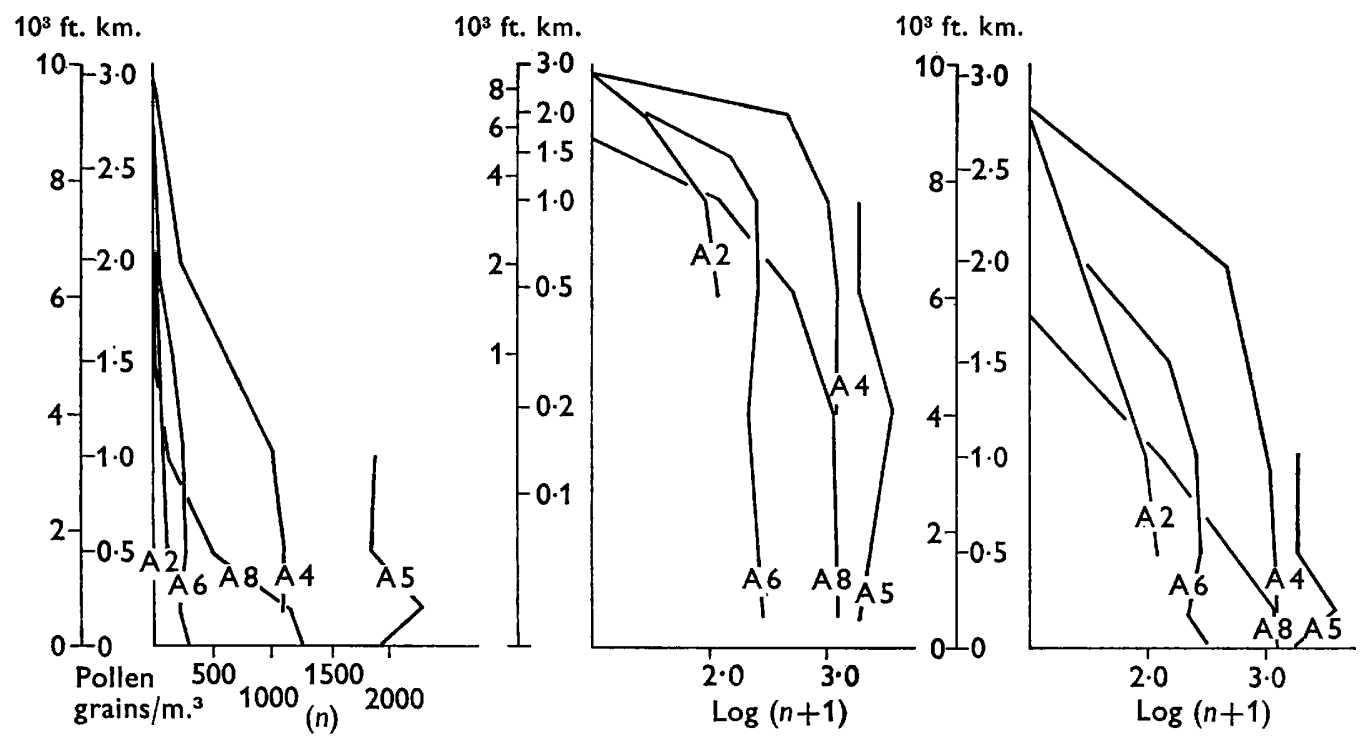

Fig. I. Vertical pollen profiles measured by Rempe (1937) presented on three scales to illustrate the advantages of $(c)$ linear height and log. spore concentration. Explanation in text.

\section{Flight plans}

Spore trapping had to be restricted to occasions when aircraft were engaged in other meteorological investigations, and flight plans had to be compatible both with with these and with air-traffic control regulations. Two types of flight are described in this paper: (I) spiral ascents or descents with straight and level portions during sampling; (2) flights, designed to intercept immigrant spore clouds, comprising a cross-wind traverse over the sea, of $100-300$ nautical miles at $600 \mathrm{~m}$., beneath civil airways (Fig. 2). (All 'miles' mentioned are nautical miles: I nautical mile $=\mathrm{I} \cdot 85 \mathrm{~km}$. All times are Greenwich Mean Time.) Near the centre of this traverse samples were collected during a spiral ascent from 300 to $3000 \mathrm{~m}$. before resuming the traverse.

\section{RESULTS}

\section{Vertical spore profiles}

Previous work suggested that spore concentration usually decreased with height, and that this change was accentuated with ascent through temperature inversions; there was also evidence of wash-out or scrubbing by rain (see Gregory, 196I). Rempe (1937) found diurnal changes in the shape of vertical spore profiles. In unstable air during the day, pollens (presumably newly released) became almost uniformly mixed in the 
lowest $1000 \mathrm{~m}$. of the air, whereas at night there was some evidence that pollens became stratified according to size, and were most concentrated at a height well above ground. Although it is difficult to accept Rempe's explanation that pollen grains collect just above inversions, other workers have also reported a 'biological zone' several hundred metres above ground where spores are most prevalent (see Gregory, I96I).

At first air was sampled during all possible ascents, to improve methods and to test suggestions that temperature lapse rate affects spores in the same way as it affects other particles suspended in air. We could seldom measure ground-level concentrations beneath the ascents but this is less serious than it might seem because ground measurements are usually much affected by local sources of spores.

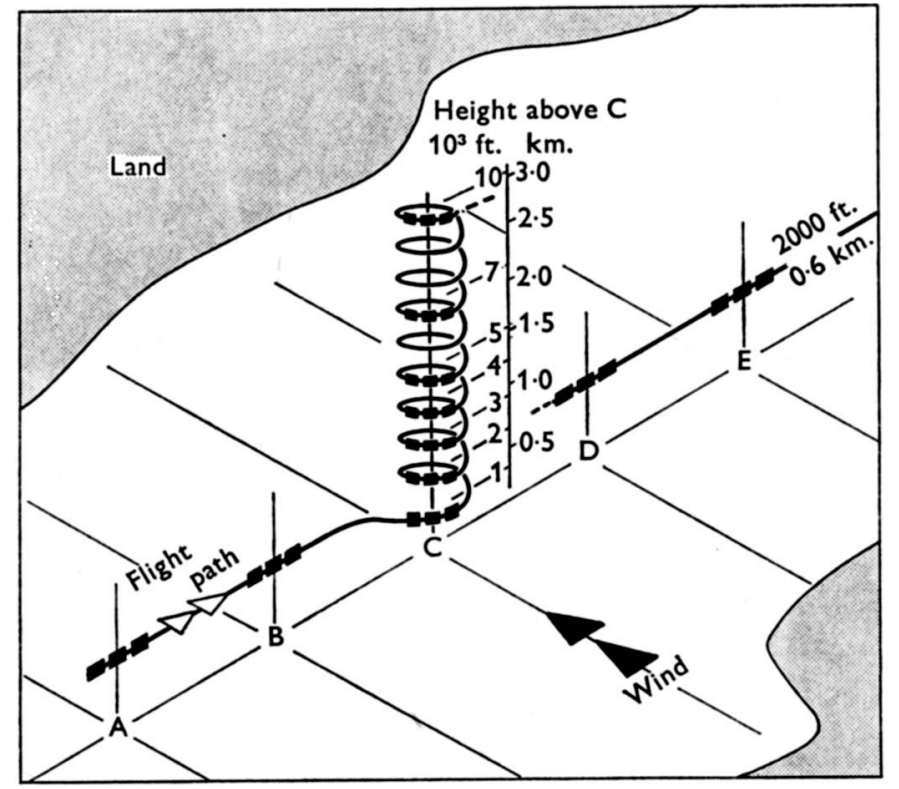

Fig. 2. Isometric diagram to illustrate flight plan used for intercepting immigrant uredospores over the English Channel. Not to scale, each black rectangle indicates an air sample.

Most spores fall slower than they move in eddies and convection, so in considering how temperature profiles are related to changes in concentration it is reasonable first to examine all spores (including pollen). Figure 3 shows profiles for six ascents partly through unstable air, the decrease in spore concentration with height is approximately logarithmic but within $900 \mathrm{~m}$. of the surface spore concentration was often almost uniform, presumably as a result of very active mixing in the friction layer. There was no consistent inverse relation between lapse rates in unstable air and the rate spore concentration decreased, as Johnson (I957) found for aphids, perhaps because the spore profiles were not only fewer, but were measured at different seasons, times of day and over both land and sea. The considerable differences in spore profiles for the ascent and descent of Flight I $3 / 57$ are not explained by the rather small differences in temperature profiles. As divergences are large only at heights between stratocumulus cloud at 900 and $2000 \mathrm{~m}$., they may reflect real heterogeneity. This possibility is supported by the closer agreement between ascent and descent profiles in Flights 9/57 and 10/57 
$10^{3} \mathrm{ft} . \quad \mathrm{km}$.

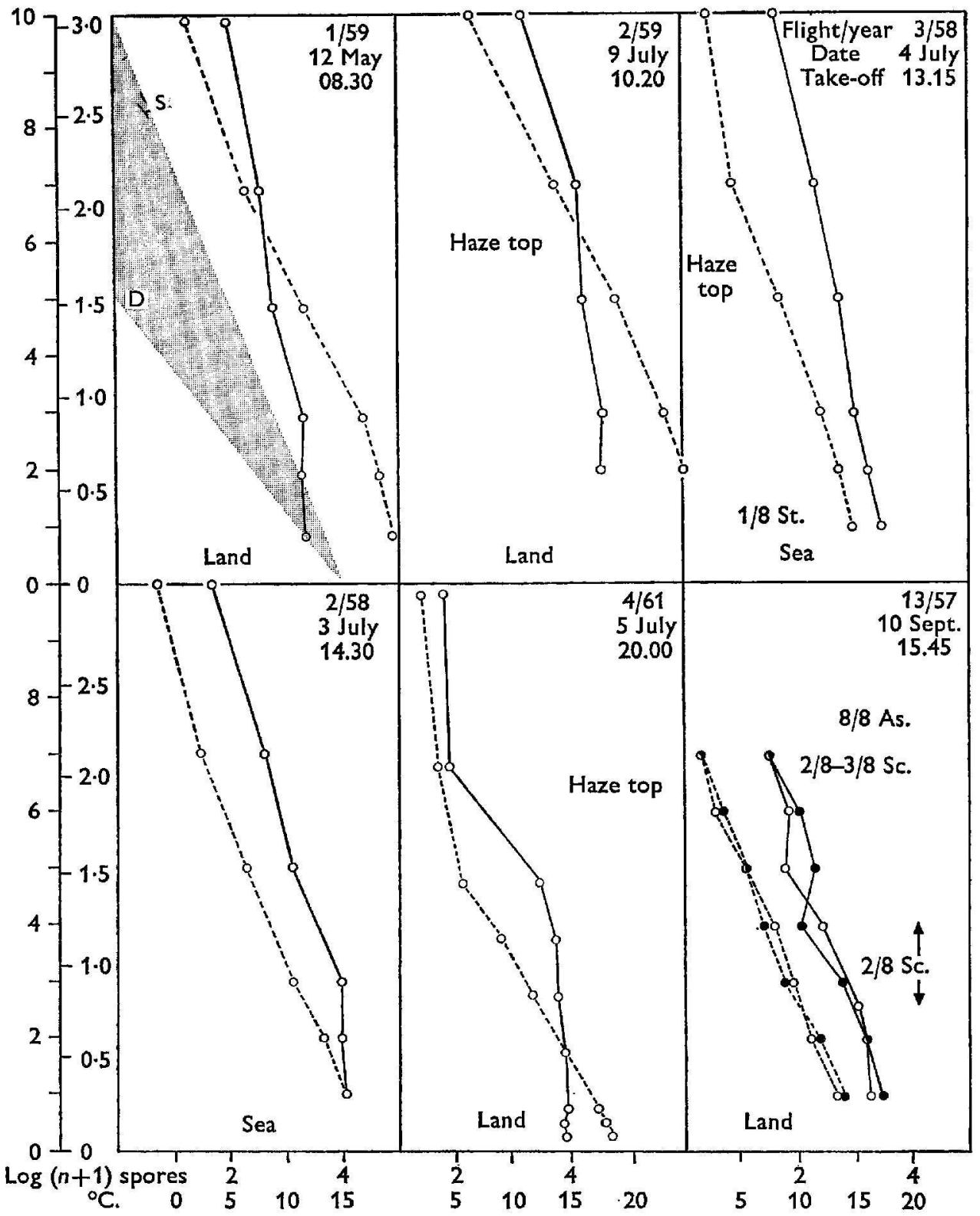

Fig. 3. Examples of vertical profiles of concentration of all spores (solid lines) in unstable or conditionally unstable air over land or sea as indicated beneath. Lower edge (D) of shaded wedge on diagram of Flight $I / 59$ indicates slope of dry adiabatic lapse rate and upper edge (S) the approximate saturated adiabatic lapse rate, temperature profiles dotted. Hollow dots indicate ascent and solid dots descent. Cloud layers indicated in 'oktas' (eighths) with standard abbreviations, arrows indicate thickness. 
$10^{3}$ ft. $\mathrm{km}$.

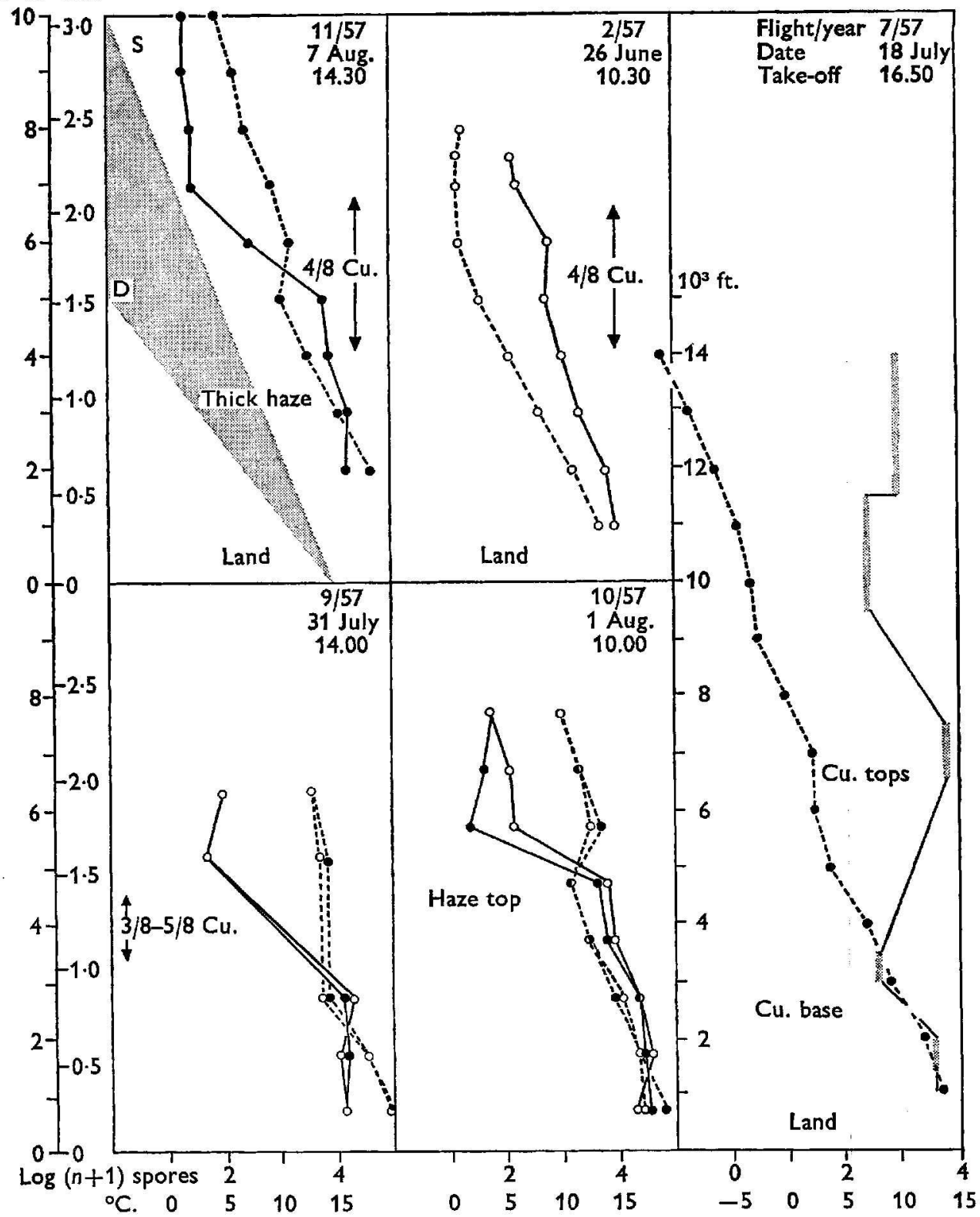

Fig. 4. Examples of vertical profiles of concentration of all spores through stable air layers. Other details as for Fig. 3, except dotted sections of profile for Flight $7 / 57$ which show layers from which samples were taken during continuous descent, see text.

(Fig. 4), both of which measured changes in concentration through temperature inversions, as did Flight I I/57 when concentrations below the cumulus layer were more than 100 times greater than above it. Sharp decreases in spore concentration often coincided with visible 'haze tops', and concentrations often decreased at cloud heights, 
presumably because there were inversions or isothermal layers. Although samples were rarely collected within clouds, Flights $2 / 57$ and 7/57 (Fig. 4) may support the contention that there are more spores inside clouds than outside (Dillon Weston, 1929; Heise \& Heise, 1948). Flight 7/57 was particularly interesting, although unfortunately another research programme dictated that the descent, over Hampshire, should be uninterrupted. Our samples were therefore unreplicated and were collected from layers of variable thickness rather than during level flight. The greatest catch (total of 6500 spores $/ \mathrm{m}^{3}$ ) was at about $2000 \mathrm{~m}$. near the cumulus tops. In contrast, only 500 spores $/ \mathrm{m}^{3}$ were caught just above cloud base at approximately $900 \mathrm{~m}$. and $4000-$ 5000 spores $/ \mathrm{m}^{3}$ below $600 \mathrm{~m}$. Showers occurred in the area and the large differences may have been caused by local rain washing. Much larger concentrations $(39,000-$ 46,000 spores $/ \mathrm{m}^{3}$ ) had been measured during the previous hour at $600 \mathrm{~m}$. in very unstable air over the Midlands.

Contemporary temperature profiles cannot explain all features of spore profiles, for example, the increase in catch at $2100 \mathrm{~m}$. in Flight 4/58 (Fig. I $a$ and p. 347) or why spore concentration did not decrease more in the stable isothermal layer above $1800 \mathrm{~m}$. in Flight 2/57 (Fig. 4). Later observations suggest that explanations require knowledge of wind direction and speed at different heights, previous temperature profiles and the past movements of the air sampled.

Within one $24 \mathrm{hr}$ period we were able to make several ascents, Fig. 5 shows results of Flights $2 / 6 \mathrm{I}$ to $7 / 6 \mathrm{I}$ with the take-off times from Farnborough, Hants. Triple samples (preceded by dummies) were collected over the same area at heights ranging from 75 to $3050 \mathrm{~m}$. and spore concentration was measured near ground level throughout the period. Temperature profiles showed that, during most flights, the air was unstable up to about $\mathrm{I} 400 \mathrm{~m}$. The exceptions were morning flights with inversions near the ground, slight in Flight 6/6I and strong in Flight 5/6I. The spore trap placed on the roof of the control tower, $12 \mathrm{~m}$. above ground, usually indicated smaller concentrations of Cladosporium conidia and pollen than those estimated from catches at the lowest height sampled by the aircraft. Had the locality been a prolific source, these dayliberated spores would have been expected to be most concentrated near the ground, however the immediate surroundings of the trap comprised much concrete runway, buildings and mown grass, with sandy heath-land beyond and probably contributed few spores. Alternatively, the smaller estimates of concentration from the surface trap may have resulted from imperfect matching of the calibration of aircraft and ground traps, errors difficult to overcome without experiments allowing both to be tested at their proper air speeds in spore clouds of equal density.

Day-time profiles of Cladosporium and pollen were alike in shape in the layers where lapse rate was enough to ensure instability and active mixing of the air. Comparison of temperature and spore profiles of Flights $6 / 6 \mathrm{I}$ and $7 / 6 \mathrm{I}$ suggests that when the height of the unstable layer increased the upper limit of dense concentrations was also raised. The earliest morning flight (5/6r) preceded the daytime increase in spore concentrations and therefore should have shown effects of the night. Neither spore type had disappeared from the air, but maximum concentrations of Cladosporium and pollen, respectively, were only $\mathrm{I} 600$ and $420 / \mathrm{m}^{3}$ during Flight $5 / 6 \mathrm{I}$, whereas they had been 7000 and 850 in Flight $4 / 6 \mathrm{I}, \mathrm{I} 2 \mathrm{hr}$ earlier, and were 4000 and $245 / \mathrm{m}^{3}$ in Flight $6 / 6 \mathrm{I}, 3 \mathrm{hr}$ later. There is a suggestion that the pollens fell farther during the night than the much lighter Cladosporium spores. Ustilago spp. (max. I I $50 / \mathrm{m}^{3}{ }^{3}$ ) were 

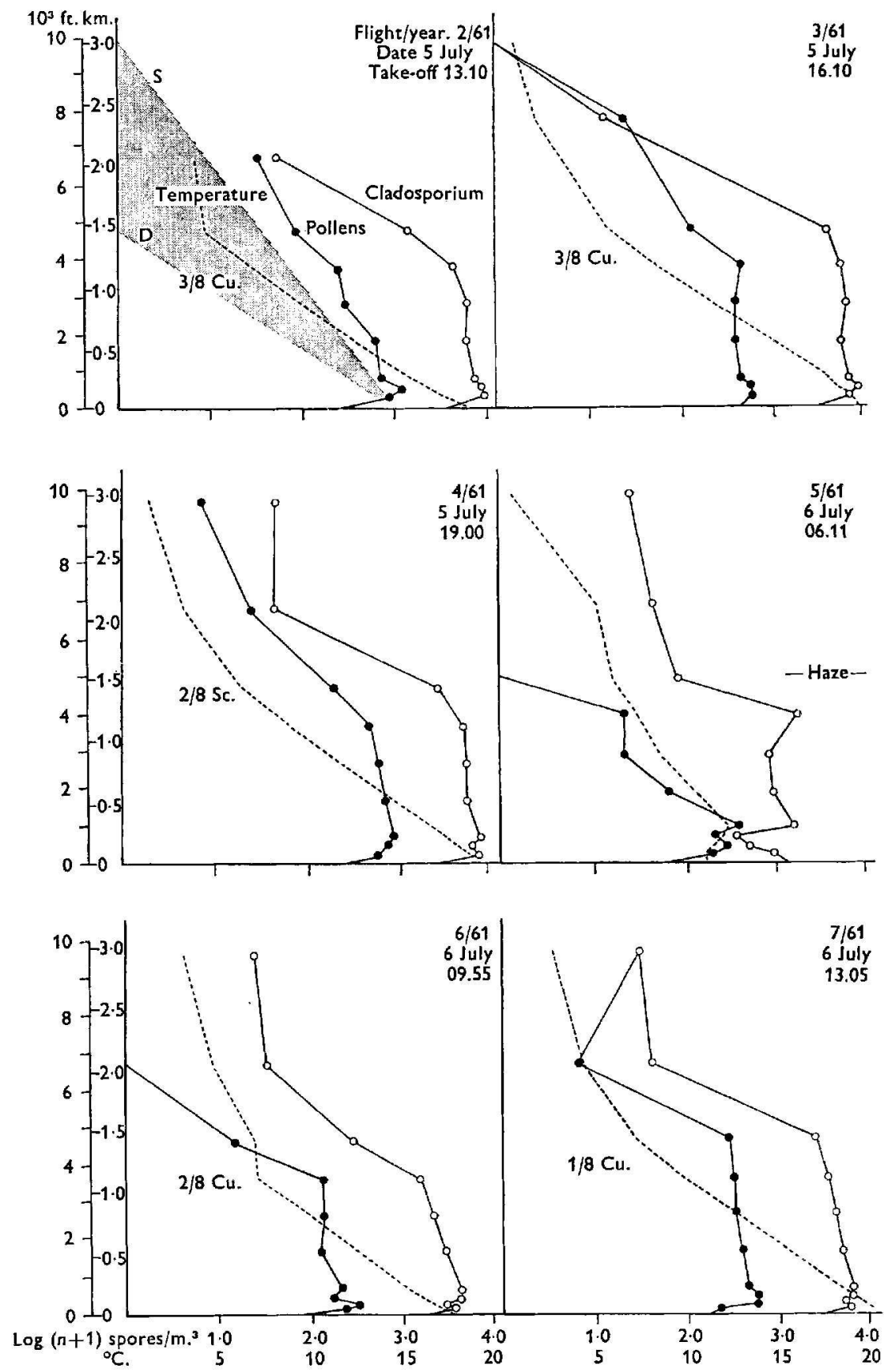

Fig. 5. Profiles of temperature (dotted), concentration of pollen (solid circles) and Cladosporium spores hollow circles) in a sequence of ascents over Farnborough, Hants. on 5 and 6 July 196I. Other details as in Fig. 3.) 
the second most common fungus spores caught in the aircraft trap, followed by Erysiphe spp. (max. 230/m. ${ }^{3}$ ), Botrytis spp. (max. I Io/m. ${ }^{3}$ ), Alternaria spp. (max. 90/m. ${ }^{3}$ ), Epicoccum $\left(\max .70 / \mathrm{m}^{3}\right)$ and coloured basidiospores (max. 60/m. ${ }^{3}$ ). Polythrincium trifolii $\left(\max .35 / \mathrm{m}^{3}\right.$ ) was almost limited to Flight 2/61. Helminthosporium, Torula and uredospores were caught on most flights but were always few. Of spores liberated in damp air only the composite 'Ascospore' group reached $90 / \mathrm{m}^{3}$, and Sporobolomyces, Tilletiopsis and hyaline basidiospores were rare.

\section{Interception of immigrant spores}

Distant seasonal movement of Puccinia graminis uredospores was demonstrated during the 1920's in North America (Stakman \& Christensen, 1946; Johnson, 1961). Comparable movements have been reported in Russia (Shitikova-Roussakova, 1927), Finland (Kivi, 1953), Australia (Watson \& Cass Smith, 1962), and in India by Mehta (1952), who first used routine air trajectories. Little was known of the spread of $P$. graminis to the British Isles until Hyde \& Adams ( $196 \mathrm{I} a, b$ ) related the presence of uredospores in catches at Cardiff with geostrophic trajectories drawn by Hogg (1961 $a, b ; 1962)$ of air arriving at Plymouth.

Figure 6 shows the occurrence of possible or probable trajectories from Iberia and France, at the 'surface', 700 and $500 \mathrm{mb}$. levels for the years 1947-59. Mr H. A. Hyde and Mrs K. F. Adams (Asthma \& Allergy Research Unit, St David's Hospital, Cardiff) have kindly allowed us to indicate days when one or more Puccinia graminis uredospores were caught, either on the Bishop Rock Lighthouse $\left(49^{\circ} 52^{\prime} \mathrm{N}, 6^{\circ} 27^{\prime} \mathrm{W}\right)$ or on the roof of the National Museum of Wales, Cardiff. Horizontal ('gravity') sticky microscope slides were used at both stations, but in and after 1957 a Hirst spore trap was used at Cardiff. Early in the period May to July few north-bound tracks carried uredospores (Fig. 6) because the disease was not yet prevalent in southern Europe. When the stem rust disease was present in southern Europe but not in Britain there was a close relation between tracks and catches, but once the disease had developed in Britain, spores were not limited to air from the south. The importance of trajectories of European origin is therefore probably greater than a casual glance at Fig. 6 suggests.

In the years 1957-59 the Meteorological Research Flight were sometimes able to sample air masses of European origin during June and early July. When it was known that a flight had intercepted immigrant Puccinia graminis uredospores hourly estimates of uredospore concentration were made from catches of spore traps continuously measuring frequency of respiratory allergens in London or Cardiff.

\section{Observations in 1957}

Flight $4 / 57 ; 13.50-14.00,4$ July 1957. Results of this first interception flight are less accurate than later ones (samples were unreplicated, giving a detection threshold concentration 30 spores $/ \mathrm{m}^{3}$ ) and incomplete because of impactor defects and the loss of some samples collected in rain. Nevertheless, the flight coincided with Puccinia graminis uredospore catches at Cardiff and on the Bishop Rock, and an ascent was completed about 30 nautical miles $\left(55.59 \mathrm{~km}\right.$.) south of Portland Bill $\left(50^{\circ} 05^{\prime} \mathrm{N}\right.$, $0^{\circ} 2^{\circ} 30^{\prime} \mathrm{W}$ ). Air was unstable throughout the profile sampled, from 1060 to $2750 \mathrm{~m}$. and single uredospores (about $30 / \mathrm{m}^{3}$ ) were caught at I200, 21 50,2450 and $2750 \mathrm{~m}$. Such small concentrations provide no information on the shape of the uredospore profile, 
J. M. HIRST, O. J. STEDMAN AND W. H. HOGG

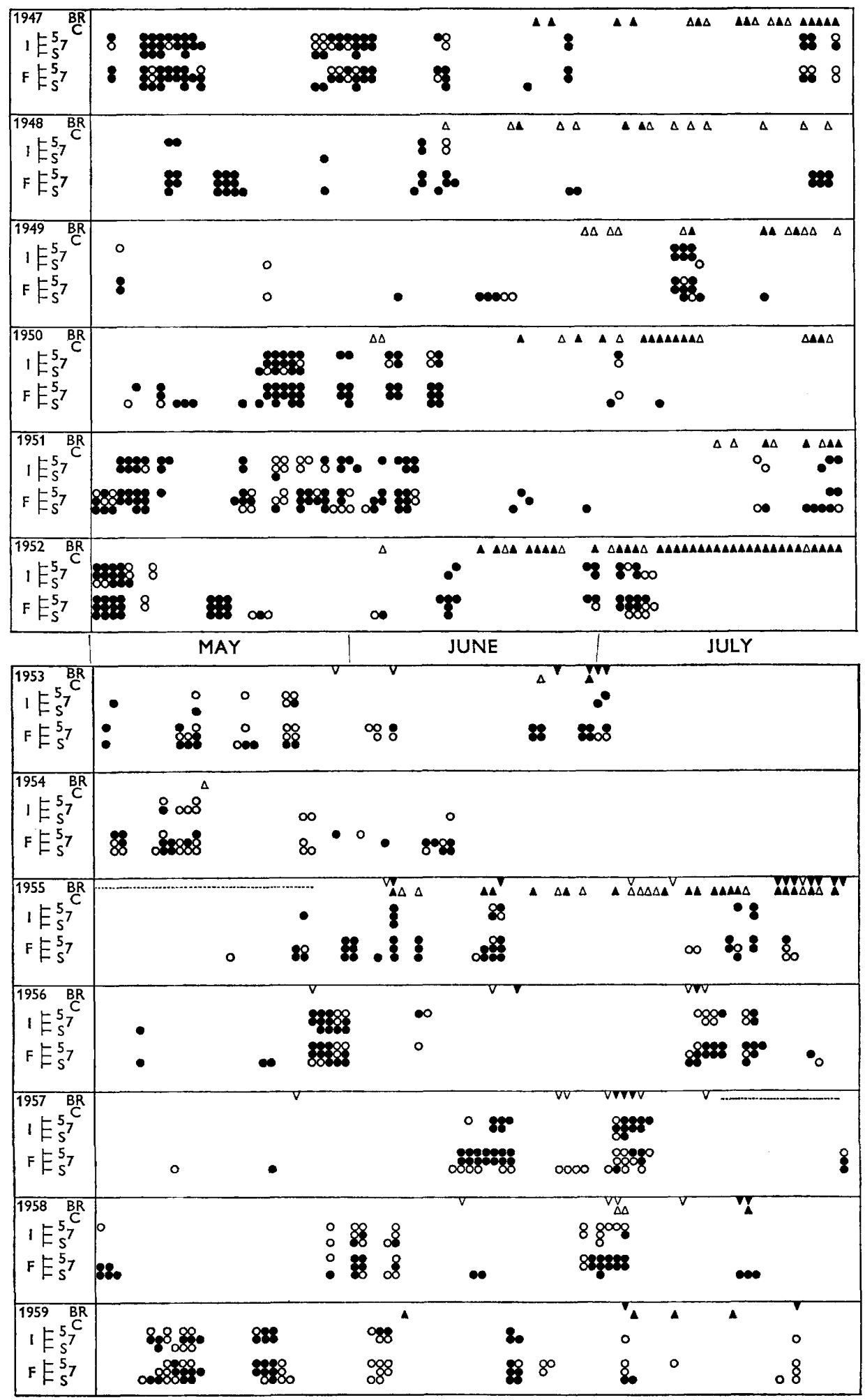

Fig. 6 For legend see opposite page. 
but because they do show when uredospores occurred well above surface air movements are useful to the discussion below.

On 3 July a slow-moving depression west of Cape Finisterre and pressure high to the east on 3 July caused a slow northward air flow over Western Europe. During the period 4-7 July the depression filled, and over Britain surface air movement became light and variable until influenced by a small secondary depression on 6 July. At the 700 and $500 \mathrm{mb}$. levels, however, the northward airflow persisted until 8 July (see Fig. 6).

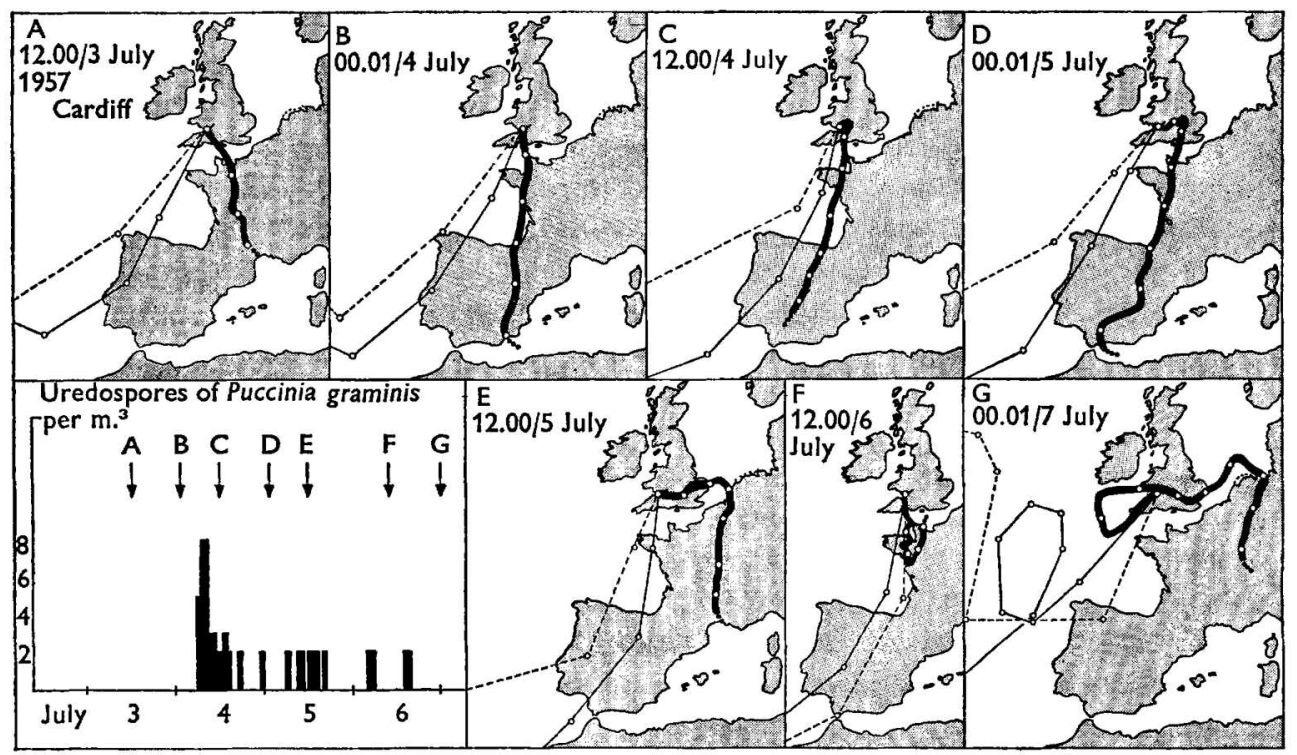

Fig. 7. Diagram showing concentration of $P$. graminis uredospores at Cardiff between 3 and 7 July 1957 and related trajectories of air arriving at Cardiff at the times indicated. Surface trajectories, thick lines; $700 \mathrm{mb}$. level, thin solid lines and $500 \mathrm{mb}$. dashed lines. Circles show estimated positions of the air sampled, at the time indicated, and at $12 \mathrm{hr}$ intervals before arrival over Cardiff.

At Cardiff surface spore catches (Fig. 7) were small even during the maximum on 4 July, but single uredospores were caught through 5 and 6 July. In view of the synoptic situation it is tempting to wonder whether the peak concentration on 4 July indicated the arrival of spore-bearing air at all heights ('solid trajectories'), whereas

Fig. 6. Upper two lines of each annual panel show $P$. graminis uredospore catches on the Bishop Rock Light House (inverted triangles) and at Cardiff (triangles with apex uppermost). At the former, 1953-59, all catches were with sticky horizontal microscope slides of which $5 \mathrm{~cm}^{2}$ was scanned, similarly at Cardiff $1947-56$. From 1957 to 1959 the Cardiff counts shown are from a single daily long axis traverse of a Hirst spore trap slide, having approximately the same sensitivity as the counts on horizontal slides. More detailed counts are available and some are used in Fig. 7. Hollow triangles indicate a single uredospore, solid triangles more than one.

Lower part of each panel indicates days when air trajectories at surface (s), 700 (7) or $500 \mathrm{mb}$. (5) possibly (hollow circle) or probably (solid circle) passed over France $(F)$ or the Iberian peninsula (I). Slides missing where the line is dotted. 
the later barely detectable concentrations represented uredospores reaching the slowmoving surface air from higher levels as a result of turbulence and gravitational settling. The evidence is insufficient to confirm or deny this hypothesis. The ascent over the English Channel, about I50 nautical miles south of Cardiff during the afternoon of 4 July, when surface catches suggested that the peak concentration had already passed, showed a few Puccinia graminis uredospores at heights up to $2750 \mathrm{~m}$. This height is representative of the $700 \mathrm{mb}$. trajectories, but the vertical distribution might have resulted either from sedimentation and downward mixing of spores carried in upper winds, or from upward convective mixing of spores arriving in surface winds. In 1957, stem rust appeared in Portugal in April and later became severe. No record has been found of its prevalence in Spain, but it is usually common by early July, although by this date in 1957 it had not been reported in Central France or Belgium. Thus, prolific sources probably lay to the south of latitude $45^{\circ} \mathrm{N}$. Surface trajectories could account for the greatest catch at Cardiff (Fig. 7) on 4 July when the air came over Spain. However, surface trajectories alone cannot explain the continued small catches at Cardiff on 6 July or those on the Bishop Rock on 2 and 3 July (Fig. 6), both of which could have resulted from spores which travelled along the faster $700 \mathrm{mb}$. trajectories.

\section{Observations in 1958}

Early in July 1958 a depression moving slowly eastwards over the Brest Peninsula into France brought air to southern England first from the south and then from the

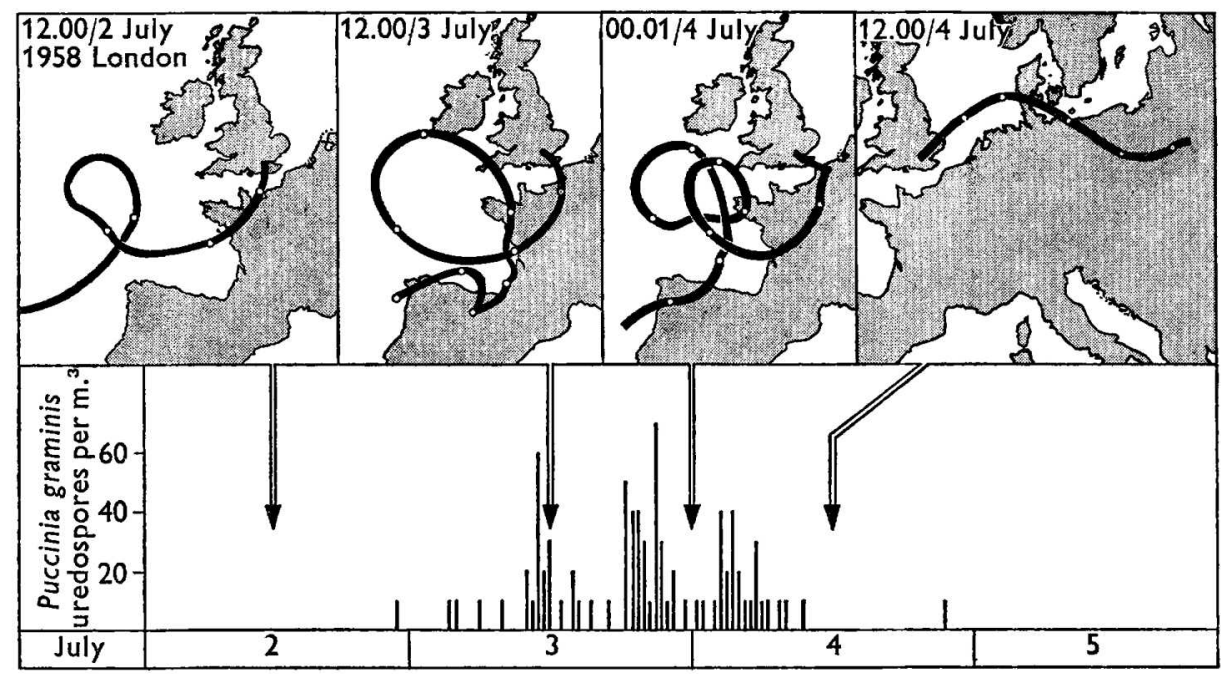

Fig. 8. Diagram showing concentrations of $P$. graminis uredospores at Paddington, London, between 2 and 5 July 1958 and related surface air trajectories. Circles show estimated positions of the air sampled at time indicated, and at $12 \mathrm{hr}$ intervals before arrival.

east. Figure 8 shows the Puccinia graminis uredospore concentrations and past trajectories of surface air arriving in London during this period. Several trajectories suggested cycloidal paths representing air movement within the depression, showing the uncertainty of prediction in view of the probable errors quoted in Table $\mathrm{I}$. Uredospores 
were caught only when trajectories passed over northern Spain and central France from midnight on 2-3 July until noon on 4 July (with a single spore later).

Flight 2/58; 12.47-14.37, 3 July 1958. Figure $9 a$ shows the course of the horizontal traverse at $600 \mathrm{~m}$. through positions 'A'-'F' with an ascent to $3050 \mathrm{~m}$. at ' D', together with the concentrations of Puccinia graminis uredospores and of all other spores. The past trajectory of air sampled at 'A' (not shown) had a much shorter travel over France than that at ' $F$ ', but the total catches differed more than the ratio

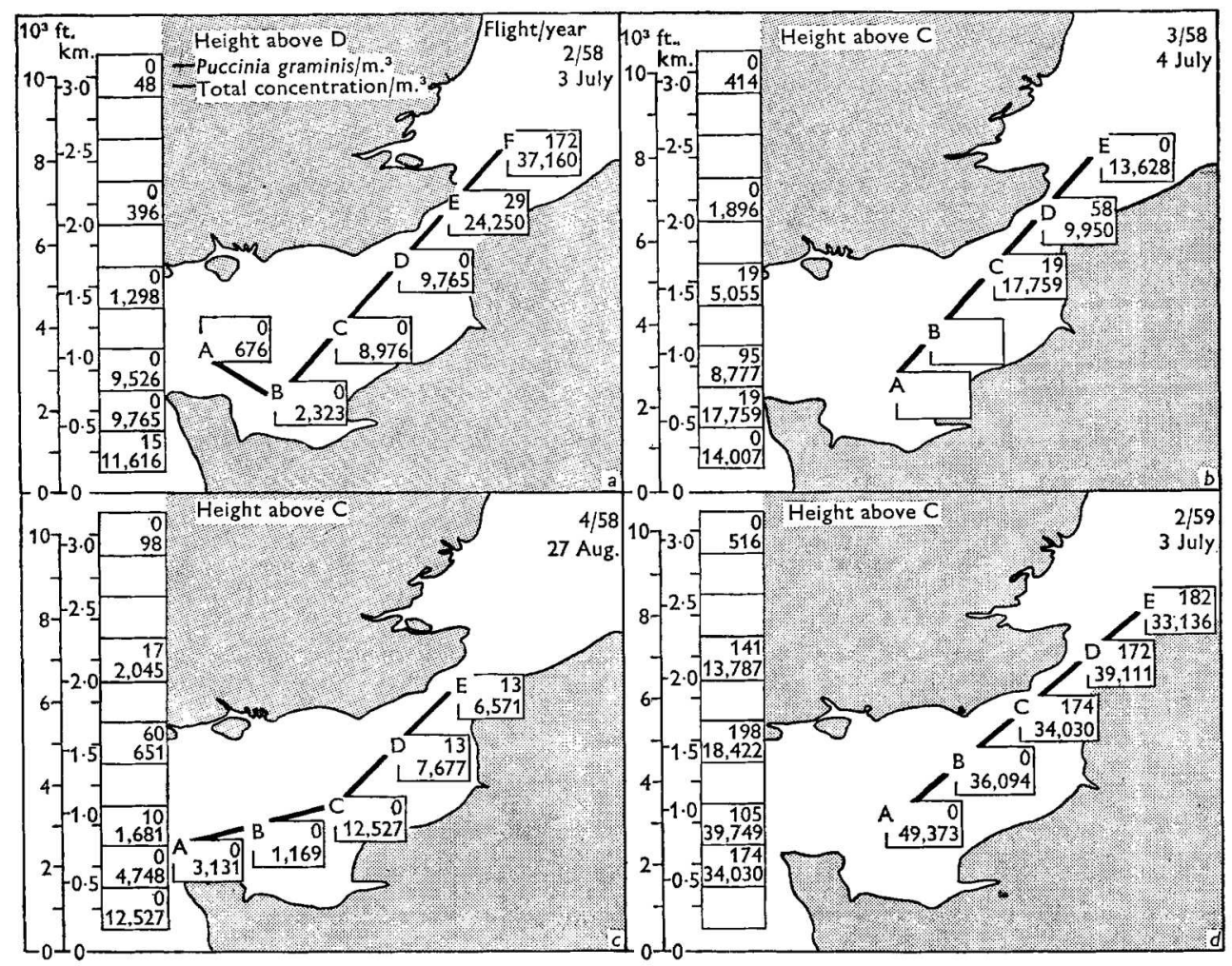

Fig. 9. Diagrams showing track of interception flights (see Fig. 2) (thick line) and sampling positions (lettered). At each position the box contains the estimated concentration of $P$. graminis uredospores (top) and all spores and pollen (bottom). For further details see text.

of distance travelled over land suggested. As most of the spores caught at ' $F$ ' were of types usually common close to the ground in daytime, the extent of daytime travel over land was examined. Air sampled at ' $F$ ' had been over France throughout 2 July, whereas air sampled at ' $A$ ' had crossed land only during the night of 2 July and briefly the following morning. Although few spore types are limited entirely to day or night liberation (Hirst, I953), the ratios of catches at ' $\mathrm{F}: \mathrm{A}$ ' of the daytime Cladosporium, Ustilago and Alternaria were, respectively, 79: r, 35: I and 94: I, whereas the predominantly nightime Sporobolomyces, Tilletiopsis and 'ascospore' groups were respectively $2: \mathrm{I}, \mathrm{I}: \mathrm{I}$ and $2: \mathrm{I}$. This supports the idea that the time as well as the distance of air-flow over land may have been important in determining spore concentrations and, in the absence of other evidence, suggests a French source for the uredo- 
spores which were commonest towards the east end of the traverse. The ascent over ' $D$ ' was too far west to intercept many uredospores, and although other spores were numerous up to $900 \mathrm{~m}$., concentration decreased rapidly above this (Fig. 10). The temperature profile approximated to the saturated adiabatic lapse rate so there would have been little convection, and contemporary temperature profiles could not account for the height distribution of spores.
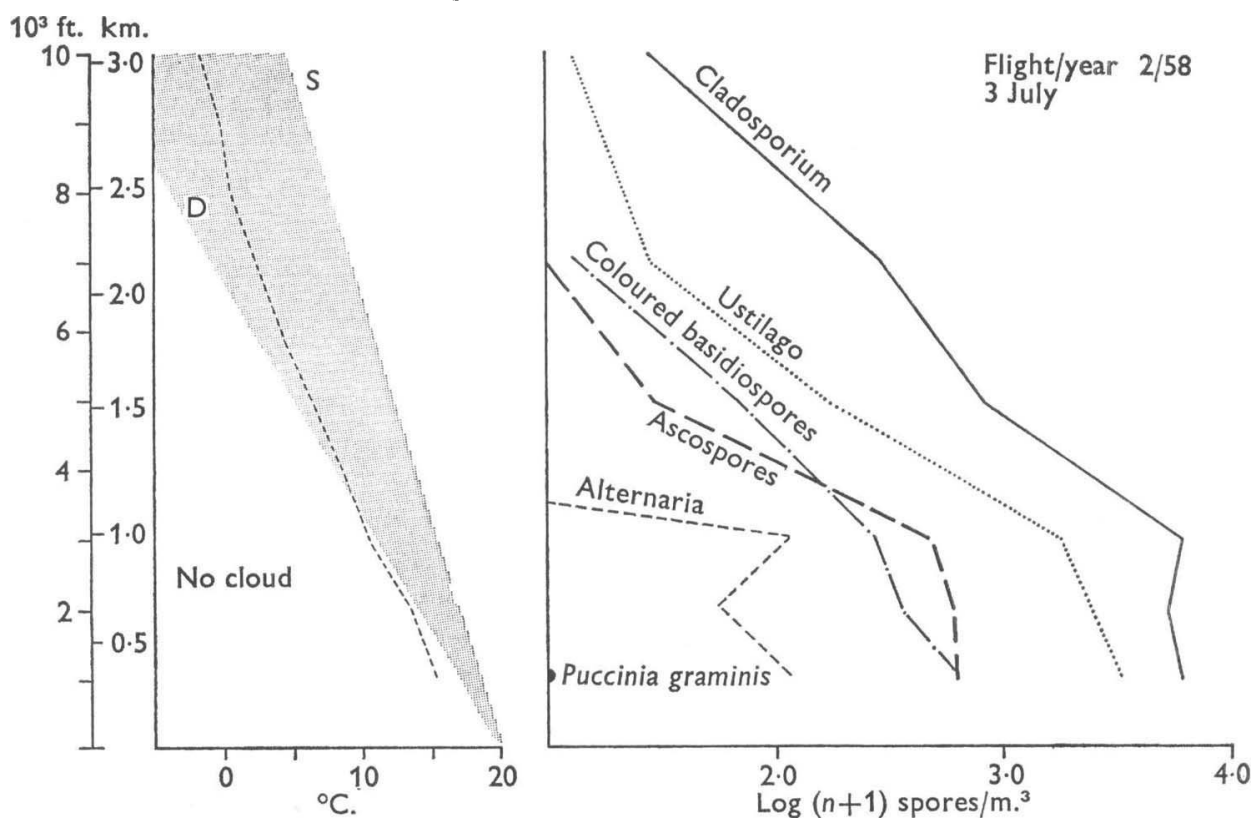

Fig. I0. Temperature profile (left) and profiles of concentrations of various spore types (right) in the ascent over D in Fig. $9 a$, Flight $2 / 58$.

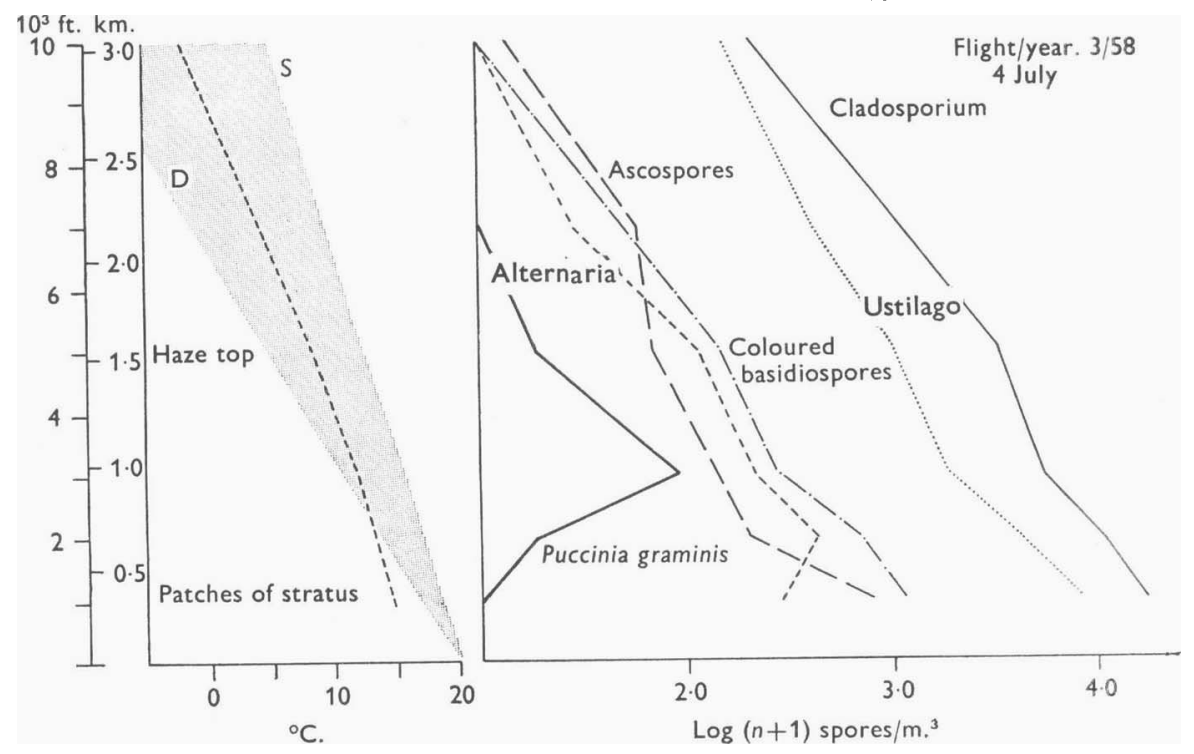

Fig. I I. Temperature profile (left) and profiles of concentrations of various spore types in the ascent over C in Fig. $9 b$, Flight $3 / 58$. 
Flight $3 / 58 ; 11.54-13.29,4$ July 1958 . An interception flight was repeated next day but, despite modifications intended to avoid cloud, samples from ' $A$ ' and ' $B$ ' were lost because of rain (Fig. $9 b$ ). Fewer spores occurred in the eastern part of the traverse than on the previous day. However, the ascent above ' $\mathrm{C}$ ' (Fig. II) was more fortunately placed. There was some instability above $900 \mathrm{~m}$. but the air was more stable beneath, with suggestions of an inversion near the surface. Above $600 \mathrm{~m}$. most profiles of $\log$. $(n+\mathrm{I})$ spores $/ \mathrm{m} .^{3}$ of air decreased almost linearly with height. More Puccinia graminis uredospores were caught than the previous day but concentrations were still small compared to other types; most were at $900 \mathrm{~m}$. Alternaria and other less common spore types were more frequent at $600 \mathrm{~m}$. than at $300 \mathrm{~m}$.
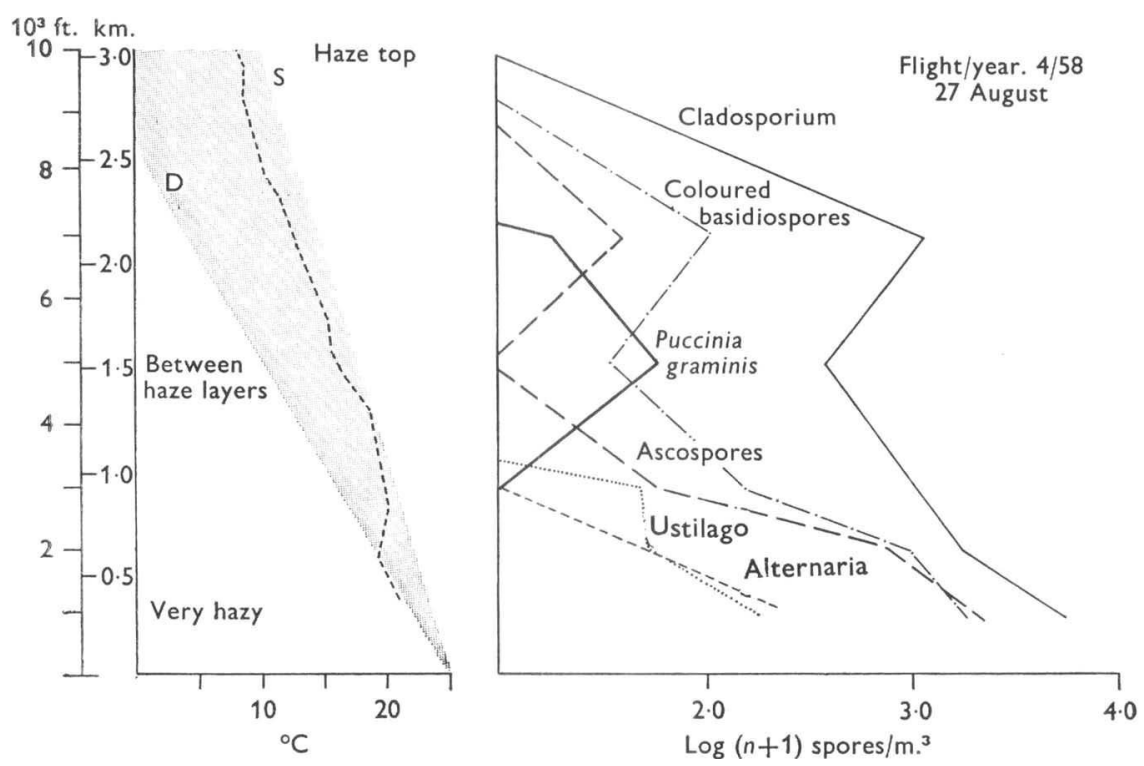

Fig. 12. Temperature profile (left) and profiles of concentrations of various spore types in the ascent over C in Fig. $9 c$, Flight $4 / 58$.

Flight 4/58; 13.39-15.03, 27 August 1958. By 27 August 1958 Puccinia graminis was present on wheat crops in central and southern England, so further uredospore introductions were of more interest aerobiologically than agriculturally. The surface trajectory of the air sampled showed that it travelled north over France on 26 August, but earlier had been over England on the 25 August. At this time a small depression passed eastwards over southern England, and behind it air moved south into France, possibly almost to the Mediterranean in the evening of the $26 \mathrm{th}$. Then an anticyclone developing over central Europe became dominant and by the time of the flight southerly winds were well established. Spore distribution was variable and again the ascent over ' $\mathrm{C}$ ' (Fig. $9 \mathrm{c}$ ) probably missed the greatest concentration of uredospores. Most spore profiles (Fig. 12) showed two dense strata at 300 and $2100 \mathrm{~m}$., but $P$. graminis was unique in showing a single peak at $1500 \mathrm{~m}$. Had the temperature inversion at $600 \mathrm{~m}$. been widespread over Europe, it could explain the rapidly decreasing concentration in the lower half of the profile but not the increased frequency of spores at $2100 \mathrm{~m}$. These spores seem to be survivors of a cloud raised by earlier convection, per- 


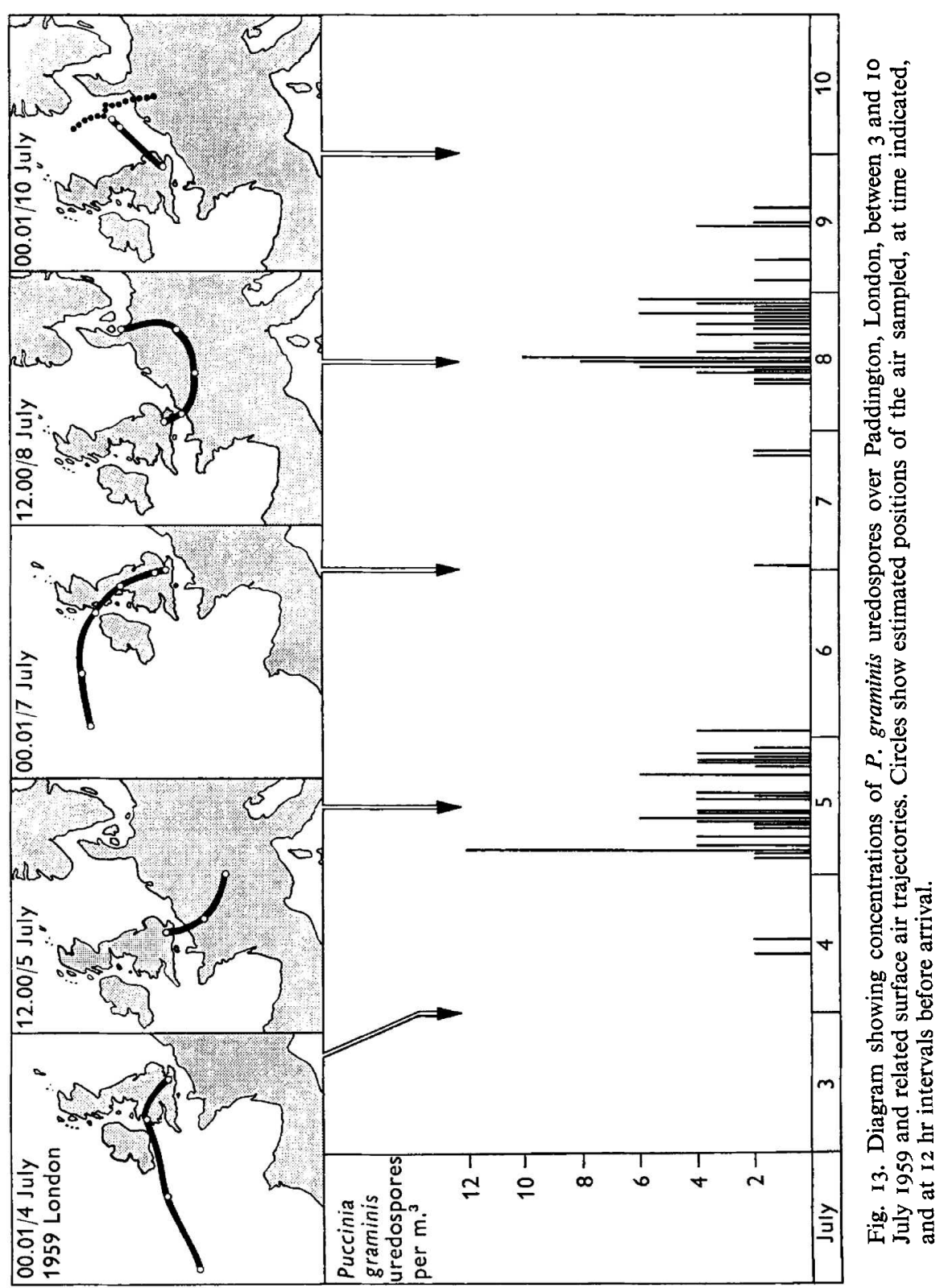


haps over France on 26 August or even over England on 25 August and retained in suspension by instability above the inversion. Even this theory fails to explain the contrasting $P$. graminis uredospore profile.

\section{Observations in 1959}

During the warm dry summer Puccinia graminis developed fast in Europe. The first record came in March from Andalusia, Spain; by early June it had spread to all except the north of the Iberian Peninsula and into south France, and by early July to north France. The uredospore introduction observed in July I959 resulted from air movements around high-pressure systems rather than depressions which were important in 1957 and 1958. An anticyclone moved slowly east from the Bay of Biscay on 2 July, across north France by 4 July and weakened over the Baltic on 6 July. A second
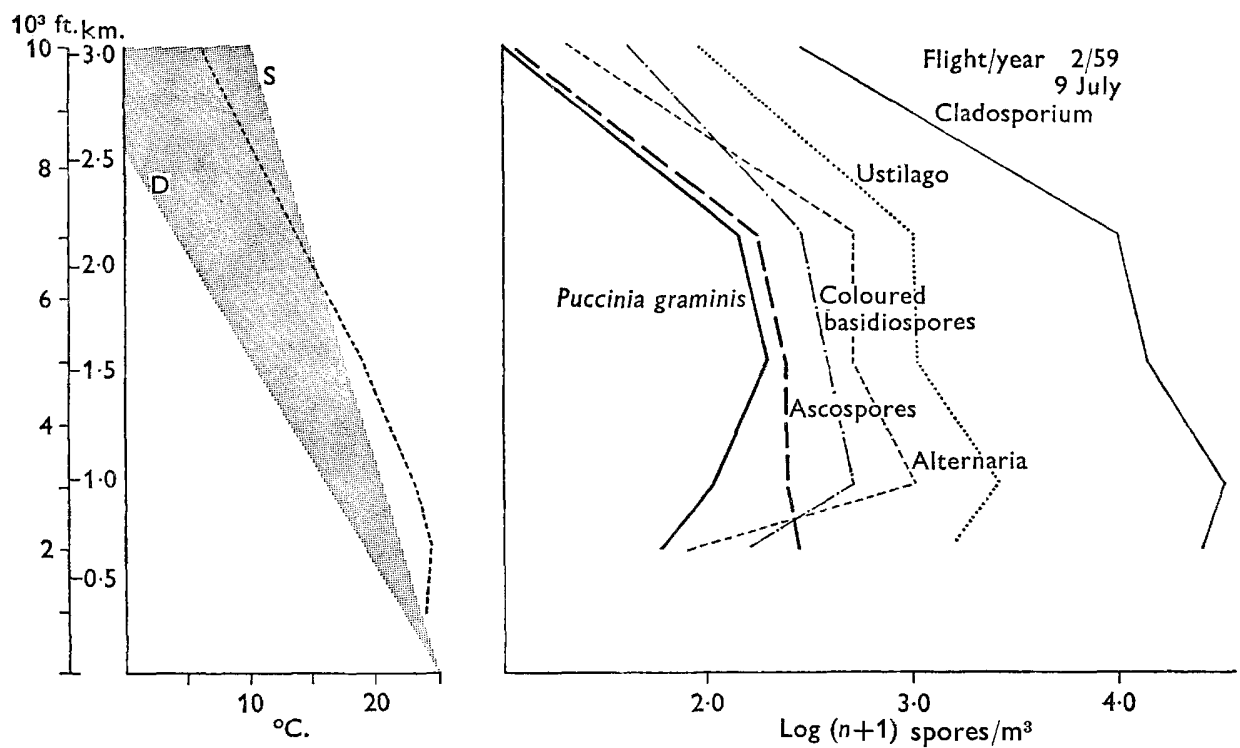

Fig. 14. Temperature profile (left) and profiles of concentrations of various spore types in the ascent over $\mathrm{C}$ in Fig. $9 d$.

anticyclone passed faster eastward over the south coast of England on 7 July and into Russia by 9 July. Figure 13 shows that northward air movement on the west side of each anticyclone brought uredospores to the trap operating in London, particularly on 5 and $8 \mathrm{July,}$ whereas the trajectories which had passed over the Atlantic were free of all but occasional uredospores, these exceptions perhaps resulting from the admitted errors of time and position which trajectories imply.

Flight 2/59;08.58-10.15, 9 July 1959. No flight could be made until almost the end of the second introduction. Most spores were common all along the traverse, but Puccinia graminis uredospores were limited to the eastern half (Fig. $9 d$ ). Hyde \& Adams (Ogilvie \& Thorpe, I96I) caught uredospores at the Bishop Rock on 4 July, and at Cardiff on 5 July during the first immigration, but only a few at Cardiff (Io July) during the second. 
An inversion below $600 \mathrm{~m}$. probably extended down to sea level, but above $900 \mathrm{~m}$. there was conditional instability (Fig. I4), so that many of the spores raised by convection before the inversion formed could remain in suspension. By contrast, below the inversion gravitational settling and frictional turbulence would combine to decrease the number of airborne spores. The agreement between the profiles of various spore types and the weather situation both suggest that most spores collected come simultaneously from the same source area. The profiles for 'ascospores' and 'unclassified' types do not share the decrease in concentration below $900 \mathrm{~m}$. and perhaps significantly both may be liberated at night.

\section{DISCUSSION}

Because of the difficulty of sampling from aircraft during rain, most flights were made during fine weather when airborne spores were probably commonest. Even allowing for this, the large concentrations found stress the frequency and potential of long-distance spore transport. Spores were caught on every occasion, $\mathrm{IO}^{4}$ spores $/ \mathrm{m} .^{3}$ were common at $600 \mathrm{~m}$., usually decreasing to hundreds $/ \mathrm{m} .^{3}$ at $3000 \mathrm{~m}$. Samples from greater heights would have been interesting, particularly in jet streams, but the small concentrations at $3000 \mathrm{~m}$. show that larger samples and prevention of contamination would be necessary to make them reliable. For the future we recognize the necessity of measuring spore viability and relating concentrations in vertical profiles to the strength of sources, ground level spore concentrations and to the number of spores deposited.

\section{The vertical distribution of spores}

The fungal flora of the atmosphere changes with time of day and the weather (Hirst, 1953), and we have selected Cladosporium to indicate convective activity because it is usually the dominant spore near the ground in daytime. Cladosporium conidia vary in length from 4 to $20 \mu$ and probably in terminal velocity from I to $5 \mathrm{~mm}$. $/ \mathrm{sec}$. or, in still air, 90-450 m./day. Spores of many other fungi lie within this range. Pollens have been used as examples of larger particles, most of which fall at $2 \mathrm{~cm}$. $/ \mathrm{sec}$. or faster, equivalent at least to $1700 \mathrm{~m}$./day.

Where convection was active, all day-liberated spore types showed similar profiles, presumably because velocities both in ascending and diffusing eddies are fast relative to settling velocities. This supports Gregory's (I96r) contention that gravitational settling can reasonably be omitted from calculations of diffusion near sources in turbulent air. But, as Schrödter (1960) pointed out, spores continue falling in turbulent air, although when convection is active the net movement of the spore cloud may be upward. In calmer conditions air may subside, and the results from flights since those reported suggest stratification of the spore cloud according to particle size (Hirst, Stedman \& Hurst, 1967; and see also Rempe, 1937).

Day-liberated spores were predominant in all vertical profiles, with Cladosporium $(80 \%$ ) followed by pollens and Ustilago at their seasonal maxima (Gregory \& Hirst, 1957). The following were the maximum concentrations of other important fungi crossing the English Channel from continental Europe: Ustilago $\left(22,000 / \mathrm{m} .{ }^{3}\right)$, Alternaria $\left(1000 / \mathrm{m}^{3}\right)$, unclassified uredospores $\left(900 / \mathrm{m}^{3}\right)$, Epicoccum $\left(500 / \mathrm{m}^{3}\right)$, Polythrincium trifolii $\left(270 / \mathrm{m}^{3}\right)$, Botrytis cinerea $\left(\mathrm{I} 4 \mathrm{O} / \mathrm{m} .^{3}\right)$, Helminthosporium $\left(40 / \mathrm{m}^{3}\right)$, Erysiphe $\left(30 / \mathrm{m}^{3}\right)$ and Entomophthoraceae $\left(\mathrm{Io} / \mathrm{m}^{3}\right)$. Venturia inaequalis conidia 
(Hirst \& Stedman, 196I) were often present (max. 90/m..$^{3}$ ) all along the transects of interception flights and once up to $2000 \mathrm{~m}$. and conidia of pear scab ( $V$. pirina) were also caught on one flight.

Marker spores to demonstrate transport processes at night are more difficult to choose, because types that are common enough are typical of damp air which may occur by day as well as at night. Of these types, ascospores (mostly coloured and multiseptate) were commonest $\left(\max .4500 / \mathrm{m}^{3}{ }^{3}\right.$. Small concentrations of hyaline basidiospores and the ballistospores of epiphytic yeasts like Sporobolomyces and Tilletiopsis were caught occasionally, but were only included in the miscellaneous category 'other classified groups'.

The dependence of spore ascent on convection is demonstrated by the rapidly decreasing concentration with ascent through temperature inversions, often visible as 'haze tops' of which spores may be an important constituent. As any spore cloud derived from ground sources diminishes in concentration with height, it is interesting to see that thorough mixing in the frictional turbulence zone often gave an almost uniform concentration in the lowest kilometre. Spores were often more concentrated above temperature inversions than below them. Rempe (I937) attributed these dense concentrations to the accumulation of spores in or above the stable air stratum, and others (see Gregory, I96I) have discussed the existence of a 'biological zone' well above the earth's surface. Accumulation could occur if spores were captured within cloud droplets and released when the drops evaporated. Otherwise there is no force to carry the spores upwards or downwards through a stable layer in eddies, and equally none to prevent them falling through it at their terminal velocity.

These abnormal profiles are more probably vestigial rather than rudimentary, the result of inversions preventing upward diffusion but not downward settling. Thus when active convection raises spores through clear air to an inversion, the position of the inversion would be marked by a rapid decrease in concentration and probably a 'haze top'. An inversion developing near the ground after a day of active convection would not impede gravitational settling or diffusion by frictional turbulence. Above this layer of depletion a zone of relatively high concentration would remain where mixing by instability could continue and spores would be removed only by settling or by capture in droplets. Such theories could be tested by studying sequences of vertical spore profiles of night- and day-liberated spores, provided the complications of intense spore liberation sometimes associated with the onset of rain were excluded (Hirst \& Stedman, 1963).

Aberrant spore profiles could result from factors other than temperature inversions, for example wash-out by rain, wind shear, or alternate travel over land and sea. More is known of the theory of spore capture by raindrops than of its effects. Drops larger than $2 \mathrm{~mm}$. diameter are most efficient in trapping spores (Langmuir, 1948; see Gregory, 1961) and in depositing them, because they fall fast and evaporate slowly. Smaller droplets falling within clouds and then evaporating provide a possible, but unproven, mechanism of vertical spore transport and a unique means of concentrating spores in some strata. Dillon Weston (I929) reported significantly more fungal and bacterial colonies on Petri dishes exposed in cloud than in clear air; Heise \& Heise (I948) also caught more ragweed pollen (Ambrosia species) and Alternaria species on sticky microscope slides exposed during flights through partial cloud cover. Unfortunately neither result proves that spores were more numerous in clouds, because the 
efficiency with which free and droplet-borne spores are deposited on such trap surfaces at air speeds of about 90 knots ( $160 \mathrm{~km}$. $/ \mathrm{hr}$ ) is unknown. Also, more organisms may grow on Petri dishes exposed in cloud because they had been better protected against desiccation and radiation. Our trapping method was equally unreliable in cloud because even the $3 \mathrm{~mm}$. orifice collected enough water to wash the trace and even to remove the adhesive layer. Consequently the aircraft avoided cloud when possible but most catches from within or between cloud were no larger than elsewhere. We have already suggested that rain modified the profile of Flight $7 / 57$, but wind shear or the history of the air sampled was sometimes more important. During Flight $4 / 57$ Cladosporium and Ustilago were the predominant fungi, at $2100 \mathrm{~m}$. the concentration of all spores was $5080 / \mathrm{m}^{3}$ compared with only $600 / \mathrm{m} .^{3}$ at $1200 \mathrm{~m}$. The flight was made before the seasonal maximum of Ustilago in England and the large concentration in the upper part of the profile was therefore probably brought by the winds from the south at 700 and $500 \mathrm{mb}$. levels (see Fig. 7 and p. 344). The two strata of dense spore concentration shown in Flight 4/58 (Fig. I I $a$ ) probably reflected the previous movement of air nearer the surface.

These modifications would affect all spore types, but profiles recorded during interception flights show exceptions, particularly Puccinia graminis uredospores and Alternaria, of which there were fewer in the lowest zones sampled than in those immediately above. We wondered whether this shape could be associated with a distant origin. Thus profiles like that of $P$. graminis in Fig. Io $b$ could be derived from the straight lines of most other spore types. When a spore cloud is blown from its source it is no longer replenished, but spores are still subject to deposition. Sedimentation and turbulent deposition will preferentially remove spores from the base of the profile, where despite their greater initial concentration 'erosion' should first be detectable by concentration decreasing. Spores of other fungi may have travelled as far as $P$. graminis, but while travelling over sources of new spores erosion would not be apparent and local and distant contributions to the profile would be indistinguishable. If this idea is correct, 'eroded' profiles of exotic spores might provide a useful means of studying the depletion of spore clouds during distant transport.

\section{Horizontal travel of spores}

Close to sources the limits of the 'dispersal cone' are reasonably well defined and determined by the ground, turbulence, and the speed and direction of the wind, but further from sources additional factors seem important. The direction of geostrophic winds approximates to the curvature of isobars; air movement is therefore seldom straight, so it is unwise to assume that spores have travelled far in the direction of the local wind. There are exceptions; for example, in the Northern Hemisphere a long and wide belt of southerly winds may occur between an anticyclone and a depression to the west of it, a situation Craigie (1945) found often responsible for the northward transport of Puccinia graminis uredospores to the mid-west and prairie wheat-growing areas of North America. This situation seemed less frequent in western Europe (see Fig. 6). Among the episodes we examined in detail, spores were carried within the circulation around both high- and low-pressure systems and successful transport demanded a delicate balance of time and motion relative to the positions of source and sink.

Sampling in Britain and over the English Channel, supported by meteorological analysis, produced convincing evidence of the immigration of Puccinia graminis uredo- 
spores and probably other plant pathogens. However, estimating the probable trajectory of air sampled on the ground at any one point and time reveals little of the distant dispersal processes because it can indicate only the probable direction of the source, not its distance. It seemed possible that trajectories might be divided into day- and nightlengths to indicate corresponding sources of spores usually most common in the air by day or night. However, spore trapping among crops showed that many 'damp-air' types are also common in damp air by day, and even spores typical of dry air could be dispersed in great quantity at the start of heavy rain (Hirst \& Stedman, 1963). Similarly, flights like those described provide only crude 'snapshots' of spore clouds during transport. Comprehensive sampling needs to be three-dimensional and repetitive. Expense prohibits such sampling, so the probable shape, size, development and depletion of spore clouds during distant dispersal will have to be inferred from orthodox meteorological data, and catches by ground traps whenever possible. Interpretation would be improved greatly by further information on the rate at which spore clouds develop above source areas and the speed at which they are depleted when moved away. These objectives seem to require more complex flights, particularly sequences of ascent during day and night, and during the travel of a spore cloud over the sea, the most convenient non-source area.

Many people have helped with this work at various times and we are grateful to all. The Director General of the Meteorological Office is specially thanked for the facilities and giving permission to publish. Nothing could have been accomplished without the willingness of the Meteorological Research Flight to add these observations to their normal duties and we are most grateful to Dr R. J. Murgatroyd, who was in charge, to Mr N. P. Garrod, Mr F. Singleton, Mr S. G. Cornford and to the air crews.

We are indebted to Mr H. A. Hyde and Mrs K. F. Adams, now of the Asthma and Allergy Research Unit, St David's Hospital, Cardiff, for permission to quote unpublished data in Fig. 6 and to Dr Elizabeth D. Hamilton for uredospore counts from the spore trap at St Mary's Hospital, London. Finally we thank Mrs Maureen Parker for her skill and patience in preparing the diagrams.

\section{REFERENCES}

AsaI, G. N. (I960). Intra- and inter-regional movement of uredospores of black stem rust in the upper Mississippi river valley. Phytopathology 5o, 535.

Chamberlain, A. C. (1956). Aspects of travel and deposition of aerosol and vapour clouds. A.E.R.E. Rep. $H P / R$ I26I. London: H.M.S.O.

Christensen, J. J. (1942). Long distance dissemination of plant pathogens. In Aerobiology. Ed. by F. R. Moulton. Publs. Am. Ass. Advmt. Sci. Publ. no. 17, p. 78

Craigie, J. H. (1945). Epidomiology of stem rust in Western Canada. Scient. Agric. 25, 285.

Craigie, J. H. (1957). Stem rust of cereals. Publ. Dep. Agric. Can. no. 666.

Dillon Weston, W. A. R. (1929). Observations on the bacterial and fungal flora of the upper air. Trans. Br. mycol. Soc. 14, III.

Durst, C. S. \& Davies, N. E. (I957). Accuracy of geostrophic trajectories. Met. Mag., Lond. 86, I 38. Gregory, P. H. (1961). The Microbiology of the Atmosphere. London: Leonard Hill Ltd.

Gregory, P. H. (1962). The dispersal distance problem. Pollen Spores, 4, 348.

Gregory, P. H. \& Hirst, J. M. (I957). The summerair-spora at Rothamsted in 1952. J. gen. Microbiol. I7, 135 .

Gregory, P. H., Longhurst, T. J. \& Sreeramulu, T. (196r). Dispersion and deposition of airborne Lycopodium and Ganoderma spores. Ann. appl. Biol. 49, 645. 
Hafsten, U. (195I). A pollen-analytic investigation of two peat deposits from Tristan da Cunha. Results Norw. Scient. Exped. Tristan da Cunha 1937-1938, no. 22, I.

Hamilton, E. D. (1959). Studies of the air spora. Acta allerg. 13, 143.

HeISE, H. A. \& HeISE, E. R. (1948). The distribution of ragweed pollen and Alternaria spores in the upper atmosphere. J. Allergy I9, 403.

Hirst, J. M. (1952). An automatic volumetric spore trap. Ann. appl. Biol. 39, 257.

HiRST, J. M. (1953). Changes in atmospheric spore content: Diurnal periodicity and the effects of weather. Trans. Br, mycol. Soc. 36, 375.

HiRst, J. M. (1959). Spore liberation and dispersal. In Plant Pathology Problems and Progress I9081958, 529. University of Wisconsin Press.

Hirst, J. M. \& HURST, G. W. (I967.) Long-distance spore transport. Symp. Soc. gen. Microbiol. $\mathbf{1 7}, 307$.

Hirst, J. M. \& Stedman, O. J. (I961). The epidemiology of apple scab (Venturia inaequalis (Cke.) Wint.) I. Frequency of airborne spores in orchards. Ann. appl. Biol. 49, 290.

Hirst, J. M. \& Stedman, O. J. (1963). Dry liberation of fungus spores by raindrops. J. gen. Microbiol. 33, 335 .

Hirst, J. M., Stedman, O. J. \& Hurst, G. W. (1967.) Long-distance spore transport: Vertical sections of spore clouds over the sea. J. gen. Microbiol. 48, 357.

HoGG, W. H. (I96I a). Meteorology in relation to recent black rust epidemics. Trans. Br. mycol. Soc. 44, 137 .

HoGG, W. H. (I96I $b$ ). The use of trajectories in black rust epidemiology. 2nd Coloquio Europeo Sobre la Roya Negra de Los Cereales, Madrid 1961.

HoGG, W. H. (1962). The use of upper air data in relation to plant disease. Mem. Univ. Coll. Wales, Aberystwyth 5, 22.

Hyde, H. A. \& AdAMs, K. F. (1961 $a$ ). Spore trapping in relation to recent black rust epidemics. Trans. Br. mycol. Soc. 44, 138.

HYDE, H. A. \& ADAMS, K. F. (I96I $b$ ). Spore trapping in relation to epidemics of black rust, 19471959. 2nd Coloquio Europeo Sobre la Roya Negra de Los Cereales, Madrid I96I.

Ingold, C. T. (1953). Dispersal in Fungi. Oxford: Clarendon Press.

INGOLD, C. T. (1965). Spore Liberation. Oxford: Clarendon Press.

Johnson, C. G. (1957). The vertical distribution of aphids in the air and the temperature lapse rate. Q. Il R. met. Soc. 83, 194.

Johnson, C. G. \& Penman, H. L. (1951). Relationship of aphid density to altitude. Nature, Lond. 168, 337.

Johnson, T. (196I). Rust research in Canada and related plant disease investigations. Publ. Dep. Agric. Can. No. 1098.

KING, J. E. \& KAPP, R. O. (I963). Modern pollen rain studies in Eastern Ontario. Can. J. Bot. 4r, 243.

KIVI, E. I. (1953). The causes of the black stem rust epidemic in Finland in summer 1951. Suom. maatal. Seur. Aikak. 25, I47.

Kramer, C. L., PAdY, S. M. \& Wiley, B. J. (1963). Kansas aeromycology. XIII. Diurnal studies I959-60. Mycologia 55, 380.

LANGMUIR, J. (1948). The production of rain by a chain reaction in cumulus clouds at temperatures above freezing. J. Met. $5,175$.

MAy, F. G. (1958). The washout of Lycopodium spores by rain. Q. Jl. R. met. Soc. 84, 45I.

MertA, K. C. (I952). Further studies on cereal rusts in India. Part II. Scient. Monogr. agric. Res. Counc. India No. I 8.

Meredith, D. S. (1963). Violent spore release in some fungi imperfecti. Ann. Bot., N.S. $27,39$.

Meteorological OfFice (1960). Handbook of Aviation Meteorology. M.O. 630 (A.P. 3340). London: H.M.S.O.

Murray, R. (1954). Accuracy of contour charts in forecasting upper winds. Prof. Notes met. Off., Lond. no. IIO.

Ogilvie, L. \& Thorpe, I. G. (196I). New light on epidemics of black stem rust of wheat. Sci. Prog. Lond. 49, 209.

Pasquill, F. (1955). Preliminary studies of the distribution of particles at medium range from a ground level point source. Porton Tech. Paper, no. 498. 
Polunin, N. \& Kelly, C. D. (1952). Arctic aerobiology. Fungi and bacteria, etc., caught in the air during flights over the geographical North Pole. Nature, Lond. 170, 314.

ReMPE, H. (I937). Untersuchungen über die Verbreitung des Blütenstaubes durch die Luftströmungen. Planta 27, 93.

SACK, S. S. (1949). How far can wind-borne pollen be disseminated? J. Allergy 20, 453.

SCHröDTER, H. (1960). Dispersal by air and water-the flight and landing. In Plant Pathology: An Advanced Treatise. Ed. by J. G. Horsfall and A. E. Dimond. vol. 3, p. I69. New York: Academic Press Inc.

Shitikova-Roussakova, A. (1927). On the question of how rust infection is introduced into the Amur region. Mater. Mikol. Fitopat. Ross. 6, I3.

Sreeramulu, T. (I958). Spore content of air over the Mediterranean sea. J. Indian Bot. 37, 220.

SReEramulu, T. (1959). The diurnal and seasonal periodicity of spores of certain plant pathogens in the air. Trans. Br. mycol. Soc. 42, 177.

Sreeramulu, T. \& Ramalingam, A. (196I). Experiments on the dispersion of Lycopodium and Podaxis spores in the air. Ann. appl. Biol. 49, 659.

Stakman, E. C. \& Christensen, C. M. (1946). Aerobiology in relation to plant disease. Bot. Rev. r2, 205.

Stakman, E. C. \& Hamilton, L. M. (1939). Stem rust in 1938. Plant. Dis. Reptr. Suppl. no. I I7, 69.

Stakman, E. C. \& Harrar, J. G. (1957). Principles of Plant Pathology. New York: Ronald.

Stakman, E. C., Henry, A. W., Curran, G. C. \& Christopher, W. N. (I923). Spores in the upper air. J. agric. Res. 24, 599.

Watson, I. A. \& CAss SMITH, W. P. (1962). Movement of wheat rusts in Australia. J. Aust. Inst. agric. Sci. 28, 279. 